\title{
YALE NATURAL RADIOCARBON MEASUREMENTS VIII
}

\author{
MINZE STUIVER, EDWARD S. DEEVEY, JR., and IRVING ROUSE
}

Geochronometric Laboratory, Department of Biology, and Department of Anthropology, Yale University, New Haven, Connecticut

\section{INTRODUCTION}

No important instrumental modifications have been made since publication of our last list (Yale VII). As before, we are indebted to many collaborators for samples and for assistance with descriptions and comments. Technical assistance has been provided by George Young, Carolyn Haupt, and Jonathan Wood. The generous support of the National Science Foundation, under grants G-19080 (to Stuiver), G-19335 (to Deevey), and G-24049 (to Rouse) is gratefully acknowledged.

As in our previous lists, dates are reported in terms of the Libby half life of $\mathrm{C}^{14}, 5570 \pm 30 \mathrm{yr}$, and geochemical measurements are expressed as $\Delta$, the normalized deviation from 95 percent of the NBS oxalic-acid standard. Infinite dates are reported as beyond a limit equal to $3 \sigma$ above background.

\section{SAMPLE DESCRIPTIONS}

I. GEOLOGIC SAMPLES

\section{A. Eastern North America}

\section{Y-1164. Birthday River, Québec}

$4110 \pm 100$

2160 в.с.

Nonsphagnous moss and sedge peat with chitinous fragments, lowest $5 \mathrm{~cm}$ of a layer $30 \mathrm{~cm}$ thick, $213 \mathrm{~cm}$ below surface, overlain by sphagnous peat, underlain by marine silty clay with Hiatella sp., exposed in undercut left bank, $1 / 2 \mathrm{mi}$ from junction of Birthday River and Harricanaw River $\left(50^{\circ} 42^{\prime} \mathrm{N} \mathrm{Lat}\right.$, $79^{\circ} 20^{\prime}$ W Long), Abitibi Territory, James Bay Lowland, Québec. Coll. 1961 and subm. by C. J. Durden, Yale Univ., for Geol. Surv. Branch, Dept. of Nat. Res., Québec. Comment (C.J.D.) : dates earliest land vegetation, following postglacial emergence, at a point $36 \mathrm{mi} \mathrm{SE}$ of the present coast. Basal peat in a similar section on Attawapiskat River, Ontario, was dated $4700 \pm 80$ (Gro1925, Groningen, unpublished). Extrapolating from the date of Y-1164, assuming constant postglacial uplift, the age of the highest beach $W$ of Seven Mile Island, on Harricanaw River, is 7900 B.P. This is comparable to dates of shells from highest marine deposits in Ontario (7875 \pm 200 , I(GSG) -14, Isotopes II ; $7280 \pm 80$, Gro-1698, Groningen, unpublished).

\section{Y-1165. Seven Mile Island, Québec}

Nonsphagnous moss peat, in laminae 1 to $3 \mathrm{~mm}$ thick, interbedded with silt and angular quartz sand, $731 \mathrm{~cm}$ depth below surface; part of a section of rhythmites, $>10 \mathrm{~m}$ thick, with couplets 3 to $20 \mathrm{~mm}$ thick, overlain with gradational contact by bluish-gray sticky clay containing Hiatella sp., $122 \mathrm{~cm}$ thick, then by river gravel, $396 \mathrm{~cm}$ thick. Exposed in undercut left bank of Harricanaw River, $2 \mathrm{mi}$ below Seven Mile Island $\left(50^{\circ} 35^{\prime} \mathrm{N}\right.$ Lat, $79^{\circ} 09^{\prime} \mathrm{W}$ Long), Abitibi Territory, James Bay Lowland, Québec. Coll. 1961 and subm. 
by C. J. Durden for Geol. Surv. Branch, Dept. of Nat. Res., Québec. Comment (C.J.D.) : the date, from a point 250 couplets below transition to marine beds, gives age of marine inundation of James Bay. The rhythmites are correlated with the Missinaibi beds of Ontario, with an age of $>53,000$ (Gro-1435, Groningen, unpublished). This is the first indication of the possibility that James Bay was ice-free during a Wisconsin interstadial.

\section{Maine bog series}

Peat and gyttja from deepest part, overlying mineral substratum, in a series of bogs in eastern Maine, situated in a belt trending NNE-SSW from nr Houlton to nr Belfast. Bogs were selected from a larger series, in which origin, rate of upward growth, and vegetation are under study by Harold Young and Richard Kennedy, School of Forestry, and E. G. Stoeckeler, Soils Laboratory, Univ. of Maine, Orono. Bogs selected are in kettles or otherwise closely related to glacial lakes; some are above and others below the probable limit of late-glacial marine overlap; deposits sampled are usually the thickest known in each district. Quadrangle references to USGS topographic maps, 15min series; coll. 1962 by Davis peat borer and subm. by Richard Kennedy.

\section{Y-1259. Littleton HL-6}

$9440 \pm 150$

From HL-6, a small bog nr Littleton, Houlton quadrangle, Aroostook County $\left(46^{\circ} 13^{\prime} \mathrm{N}\right.$ Lat, $67^{\circ} 52^{\prime} \mathrm{W}$ Long), surface alt $440 \mathrm{ft}, 411 / 2$ to $42 \mathrm{ft}$ depth.

\section{Y-1253. Hershey SH-2}

$10,140 \pm 120$ 8190 B.c.

From SH-2, a large bog nr Hershey, Sherman quadrangle, Penobscot County $\left(45^{\circ} 49^{\prime} \mathrm{N} \mathrm{Lat}, 68^{\circ} 26^{\prime} \mathrm{W}\right.$ Long), surface alt $420 \mathrm{ft}, 13 \frac{1}{2}$ to $13 \frac{1}{4} \mathrm{ft}$ depth.

\section{Y-1256. Topsfield WA-3}

$10,560 \pm 150$ 8610 в.c.

From WA-3, a large bog nr Topsfield, Waite quadrangle, Washington County $\left(45^{\circ} 27^{\prime} \mathrm{N}\right.$ Lat, $67^{\circ} 45^{\prime} \mathrm{W}$ Long $)$, surface alt $550 \mathrm{ft}, 251 / 2$ to $26 \mathrm{ft}$ depth.

\section{Y-1257. Codyville WA-6}

$9120 \pm 160$

7170 в.c.

From WA-6, a large bog nr Codyville, Waite quadrangle, Washington County $\left(45^{\circ} 26^{\prime} \mathrm{N}\right.$ Lat, $67^{\circ} 41^{\prime} \mathrm{W}$ Long $)$, surface alt $370 \mathrm{ft}, 23$ to $231 / 4 \mathrm{ft}$ depth.

\section{Y-1252. Chester LN-1}

$9960 \pm 150$ 8010 в.c.

From LN-1, a small bog nr Chester, Lincoln quadrangle, Penobscot County ( $45^{\circ} 30^{\prime} \mathrm{N}$ Lat, $68^{\circ} 33^{\prime} \mathrm{W}$ Long), surface alt $280 \mathrm{ft}, 19$ to $191 / 4 \mathrm{ft}$ depth.

\section{Y-1249. Howland PA-9}

$10,040 \pm 120$ 8090 в.C.

From PA-9, a small bog nr Howland, Passadumkeag quadrangle, Penobscot County $\left(45^{\circ} 13^{\prime} \mathrm{N}\right.$ Lat, $68^{\circ} 43^{\prime} \mathrm{W}$ Long), surface alt $220 \mathrm{ft}, 91 / 2$ to $93 / 4$ $\mathrm{ft}$ depth. 
Y-1251. Passadumkeag PA-23

$9620 \pm 150$

7670 в.с.

From PA-23, a small bog nr Passadumkeag, Passadumkeag quadrangle, Penobscot County $\left(45^{\circ} 13^{\prime} \mathrm{N}\right.$ Lat, $68^{\circ} 35^{\prime} \mathrm{W}$ Long $)$, surface alt $160 \mathrm{ft}, 291 / 2$ to $293 / 4 \mathrm{ft}$ depth.

\section{Y-1250. Alton PA-16}

$5410 \pm 80$

3460 в.c.

From PA-16, a small bog nr Alton, Passadumkeag quadrangle, Penobscot County $\left(45^{\circ} 02^{\prime} \mathrm{N}\right.$ Lat, $68^{\circ} 44^{\prime} \mathrm{W}$ Long), surface alt $220 \mathrm{ft}, 41 / 2$ to $43 / 4 \mathrm{ft}$ depth. Comment: this anomalously young sample proved not to be the deepest in the bog; Y-1312 gives an acceptable result.

\section{Y-1312. Alton PA-16, bottom}

$8940 \pm 120$

From PA-16, a new sample to check Y-1250, 71/4 to $71 / 2 \mathrm{ft}$ depth.

\section{Y-1255. Bingham BG-1}

$9410 \pm 120$

7460 в.с.

From BG-1, a small bog nr Bingham, Bingham quadrangle, Somerset County $\left(45^{\circ} 04^{\prime} \mathrm{N}\right.$ Lat, $69^{\circ} 54^{\prime} \mathrm{W}$ Long), surface alt $440 \mathrm{ft}, 28$ to $29 \mathrm{ft}$ depth.

\section{Y-1258. Stillwater OR-3}

$9730 \pm 160$ 7780 в.с.

From OR-3, a small bog nr Stillwater, Orono quadrangle, Penobscot County (44. $56^{\prime} \mathrm{N}$ Lat, $68^{\circ} 42^{\prime} \mathrm{W}$ Long), surface alt $120 \mathrm{ft}, 12 \frac{1}{2}$ to $13 \mathrm{ft}$ depth.

\section{Y-1254. Hermon BA-8}

$9610 \pm 120$

From BA.8, a large bog $\mathrm{nr}$ Hermon, $\mathbf{7 6 6 0 \text { в.C. }}$ County $\left(44^{\circ} 48^{\prime}\right.$ N Lat, $68^{\circ} 54^{\prime}$ W Hermon, Bangor quadrangle, Penobscot County $\left(44^{\circ} 48^{\prime} \mathrm{N}\right.$ Lat, $68^{\circ} 54^{\prime} \mathrm{W}$ Long), surface alt $130 \mathrm{ft}, 293 / 4$ to $30 \mathrm{ft}$
depth.

\section{Y-1260. Searsport CT-1}

$9630 \pm 150$

From CT-1, a large bog nr Searsport, Castine quadrangle, Waldo County ( $44^{\circ} 29^{\prime} \mathrm{N}$ Lat, $69^{\circ} 57^{\prime} \mathrm{W}$ Long), surface alt $240 \mathrm{ft}, 27$ to $28 \mathrm{ft}$ depth.

Comment: despite a considerable range of maximum thickness of organic deposit, from ca. 10 to ca. $42 \mathrm{ft}$, the oldest organic samples are remarkably uniform in age, $9690 \pm 430 \mathrm{yr}$, over a wide geographical and altitudinal range. Deglaciation of the sites was evidently nearly simultaneous; the time lag before inception of organic deposition, often thought to invalidate such dates as a measure of time of deglaciation, seems hardly to have exceeded the statistical uncertainty of any single date. If there are differences. apart from the difficulty, in large and complex bog systems, of finding the deepest and oldest deposits, they may be of two sorts: those due to early emergence of high altitudes from a stagnant ice sheet, and those due to delayed uncovering of low-lying bogs by the late-glacial sea. WA-3 (Y-1256) may be the oldest bog for the first reason; PA-23, OR-3, and BA-8 (Y-1251, 1258, 1254), all below $220 \mathrm{ft}$, may be examples of the second, being younger, though not significantly so, than LN-1 and SH-2 (Y.1252, 1253), which lie above $280 \mathrm{ft}$. Emergence of Maine's 
coastal belt from the late-glacial sea, the result of crustal upwarping, brought strandline features to altitudes of $200 \mathrm{ft}$ near the coast and $300 \mathrm{ft}$ farther inland (Bloom, 1960). The inference that uplift occurred about 10,000 yr ago is not in serious conflict with Bloom's argument, drawn from two pollen diagrams, that emergence took place early in the time of the pine zone, an estimated 7000-8000 yr ago. Pine-pollen time is not directly dated in coastal Maine, and may well have begun before 10,000 B.P. Evidence that isostatic response to glacial unloading was immediate and rapid is given for Greenland by Washburn and Stuiver (1962).

\section{Barnstable Marsh series, Massachusetts}

Salt-marsh peat, collected by piston corer at four localities on marsh fringing $S$ side of Sandy Neck, a spit that shelters Barnstable Harbor (Hyannis quadrangle, USGS topog. map; USC \& GS Chart 339), N shore of Cape Cod, Massachusetts. Coll. 1961 by A. C. Redfield and A. E. Doe, Woods Hole Oceanographic Inst., to determine (a) rate of vertical accretion of marsh during intertidal stage, before high-marsh stage has been reached, and (b) chronology of eastward growth of Sandy Neck. Dates covering vertical accretion of highmarsh peat were obtained by the USGS laboratory, with results implying upward growth (and relative rise of sealevel) of $0.33 \mathrm{ft}$ per century since 2100 B.P., and of $1.0 \mathrm{ft}$ per century prior to that time (Redfield and Rubin, 1962). Bottommost peat samples, overlying sandy substratum, were dated at each locality in order to minimize errors of vertical position due to compaction, and one sample at intermediate depth was also dated at three of the four localities. Depths were measured below marsh surface, which is approximately at MHW. Samples were 6 in. long. Subm. by A. C. Redfield.

\section{Y-1184. Cove, C 3.3} $70^{\circ} 17^{\prime} 33^{\prime \prime} \mathrm{W}$ Long), $4700 \mathrm{ft} \mathrm{W}$ of tip of Sandy Neck.

\section{Y-1185. Bass Creek, BA 3.0}

Fibrous peat, $3.0 \pm 0.25 \mathrm{ft}$ depth, Bass Creek $\left(41^{\circ} 43^{\prime} 34^{\prime \prime}\right.$ N Lat, $70^{\circ} 18^{\prime}$ $10^{\prime \prime} \mathrm{W}$ Long), $2300 \mathrm{ft} \mathrm{W}$ of Cove.

\section{Y-1186. Bass Creek, BA 7.9-2}

$$
1400 \pm 80
$$

Bottommost organic sand, $7.9 \pm 0.25 \mathrm{ft}$ depth, Bass Creek; the more organic of two samples at this level.

\section{Y-1187. Braileys, BR 6.5}

$710 \pm 80$

Silty peat, $6.5 \pm 0.25 \mathrm{ft}$ depth, Braileys $\left(41^{\circ} 43^{\prime} 45^{\prime \prime}\right.$ N Lat, $70^{\circ} 19^{\prime} 15^{\prime \prime}$ W Long), $5450 \mathrm{ft}$ W of Bass Creek.

\section{Y-1190. Braileys, BR 7.8}

$$
1060 \pm 100
$$

Organic silt nr bottom, $7.8 \pm 0.25 \mathrm{ft}$ depth, Braileys. Maximum depth of peat (by probing) was $9.0 \mathrm{ft}$ at this site, but no deeper sample could be obtained. 
Y-1188. Keith's, K 3

$\mathbf{2 4 0} \pm \mathbf{8 0}$

Fibrous peat, $3.0 \pm 0.25 \mathrm{ft}$ depth, Keith's $\left(41^{\circ} 43^{\prime} 50^{\prime \prime} \mathrm{N}\right.$ Lat, $70^{\circ} 20^{\prime}$

$52^{\prime \prime}$ W Long), $7110 \mathrm{ft} \mathrm{W}$ of Braileys, nr base of Sandy Neck.

\section{Y-1189. Keith's K 13.7}

$2200 \pm 100$

Bottommost organic sand, $13.7 \pm 0.25 \mathrm{ft}$ depth, Keith's.

Comment (A.C.R.) : a sample previously obtained, W-1099 (see Redfield and Rubin, 1962) from near the base of Sandy Neck and 11,200 ft W of Keith's indicated that marsh had developed in the shelter of the spit by $3170 \pm 300$ B.P., thus giving a minimal age for the spit. Combining this date with those of the oldest samples of the present series, the fringe of marsh sheltered by Sandy Neck spread eastward for the first two miles at a rate of ca. $11 \mathrm{ft}$ per yr. For the second two miles the rate was ca. $9 \mathrm{ft}$ per yr, and for the last half mile ca. $2 \mathrm{ft}$ per yr. The sand spit presumably grew eastward in advance of the peat fringe, but at approximately the same rates. It has advanced at ca. $2 \mathrm{ft}$ per yr during the past $100 \mathrm{yr}$. Sample Y-1190 from Braileys has been neglected in these estimates. It is younger than the bottom sample at Bass Creek and it is possible that the marsh at Braileys was destroyed by erosion during its earlier history. The rate of vertical accretion of the peat cannot be commented on profitably until the complete series of samples at intermediate depths has been dated. The deeper layers of peat in this series developed at intertidal levels and grew upward at rates determined by sedimentation rather than by rising sea level. Because of more rapid accretion during the intertidal stage, the age of the bottom sample is less than that of samples from similar depths at places where high-marsh peat has developed as the upland was flooded by rising sea levels.

\section{Hammock River marsh series, Connecticut}

Peat, peaty sand, and wood from a layer underlying a wedge of estuarine mud in S part of Hammock River tidal marsh $\left(41^{\circ} 15.7^{\prime} \mathrm{N} \mathrm{Lat}, 72^{\circ} 30.7^{\prime} \mathrm{W}\right.$ Long), Clinton, Connecticut. The overlying mud thickens toward NE from ca. 3 to ca. $36 \mathrm{ft}$. Most samples coll. 1961 by Davis borer at the top of the peat bed have been displaced by, and measure the amount of, compaction; samples at base of peat, overlying firm sandy substratum, mostly coll. 1962, give more reliable data on rate of marine submergence (Bloom and Stuiver, 1963). Datum is marsh surface, which is within $\pm 0.2 \mathrm{ft}$ of MHW. The marsh is the deepest and oldest yet discovered on the Connecticut coast. Subm. by A. L. Bloom, Cornell Univ., Ithaca, N. Y.

\section{Y-1055. Hammock River 7-14-1}

Peaty sand, $33.3 \pm 0.4 \mathrm{ft}$ below surface.

$$
\begin{aligned}
& 7060 \pm 100 \\
& 5110 \text { в.C. }
\end{aligned}
$$

Y-1056. Hammock River 7-13-6

$$
4780 \pm 130
$$$$
2830 \text { B.C. }
$$

Sedge peat from top $2 \mathrm{in}$. of a 1.2-ft layer, $27.2 \pm 0.3 \mathrm{ft}$ below surface. 


\section{Y-1057. Hammock River 7-13-5}

Sedge peat from top $2 \mathrm{in}$. of 2.6 -ft layer, $18.6 \pm 0.3 \mathrm{ft}$ below surface.

Y-1058. Hammock River 7-13-1

$3450 \pm 160$

1500 в.C.

Sedge peat from top $2 \mathrm{in}$. of a $3.2 \mathrm{ft}$ layer, $15.6 \pm 0.3 \mathrm{ft}$ below surface.

Y-1059. Hammock River 7-12-3

$1280 \pm 150$

Sedge peat from top $2 \mathrm{in}$. of a 2.8 -ft layer, $10.7 \pm 0.3 \mathrm{ft}$ below surface.
Y-1074. Hammock River 35.7 ft
$6130 \pm 90$
4180 в.c.

Sedge peat from top $3 \mathrm{in}$. of a 2.3 -ft layer, $35.7 \pm 0.4 \mathrm{ft}$ below surface.

\section{Y-1175. Hammock River 6-6-1}

$3020 \pm 90$

1070 в.C.

Sedge peat from bottom $2 \mathrm{in}$. of a $3.5-\mathrm{ft}$ layer, $9.1 \pm 0.6 \mathrm{ft}$ below surface.

Y-1176. Hammock River 6-6-3

$3220 \pm 90$

1270 в.c.

Sedge peat from bottom 3 in. of a 3.5 -ft layer, $11.4 \pm 0.5 \mathrm{ft}$ below surface.

\section{Y-1177. Hammock River 6-5-1}

$4880 \pm 120$

2930 в.c.

Wood and bark from base of $3-\mathrm{ft}$ peat layer, $19.6 \pm 0.5 \mathrm{ft}$ below surface.

\section{Y-1178. Hammock River 6-7-1}

$11,240 \pm 160$

9290 в.c.

Sedge peat, composite of 2 samples $50 \mathrm{ft}$ apart, $36.6 \pm 0.5$ to $37.7 \pm 0.3$ $\mathrm{ft}$ below surface.

Comment: disregarding samples affected by compaction, Bloom and Stuiver (1963) computed the submergence between 7060 B.P. (Y-1055) and 3020 B.P. (Y-1175) to have been $0.6 \mathrm{ft}$ per century, from -33 to $-9 \mathrm{ft}$ below present MHW. Thereafter, as also shown at Barnstable Marsh (Redfield and Rubin, 1962), the rate decreased by about half, to $0.3 \mathrm{ft}$ per century. Because the slope of the buried valley under the Hammock River marsh, to seaward of Y-1055, is not uniform, the relation of Y-1178 to the other samples is problematical; older but not much deeper than the others, the sample is believed to give only a minimum figure for submergence between 11,240 and 7060 B.P.

\section{Y-1054. East Norwalk, Connecticut}

$1400 \pm 70$

\section{A.D. 550}

Root from tree stump, exposed in drainage ditch on tidal marsh, ca. 400 $\mathrm{ft} \mathrm{S}$ of Saugatuck Avenue on SE edge of Shorehaven Golf Course $\left(41^{\circ} 06^{\prime} \mathrm{N}\right.$ Lat, $73^{\circ} 23.3^{\prime}$ W Long), East Norwalk, Connecticut. Stump roots penetrated gravel, probably glacial drift, through a zone 36 to 48 in. below surface of marsh. Tree probably killed by salt-water inundation of root system 48 in. below present MHW; stump is overlain by muddy salt-marsh peat recording at 
least 48 in. of marine submergence. Coll. 1961 and subm. by A. L. Bloom. Comment: no correction for compaction is needed; sample agrees closely with Y-840 and Y-855 (Yale VI) in establishing recent submergence along Connecticut shore at a rate of $0.3 \mathrm{ft}$ per century. Relation of this sample and calculated rate to other Connecticut data is shown by diagram in Bloom and Stuiver (1963, fig. 1).

\section{Y-1077. North Haven, Connecticut}

$3560 \pm 80$

1610 B.C.

Log, overlain by $6 \mathrm{ft}$ of estuarine peat, underlain by $3.5 \mathrm{ft}$ of gray sandy silt, S side of clay pit $\left(41^{\circ} 22^{\prime} \mathrm{N}\right.$ Lat, $72^{\circ} 53^{\prime} \mathrm{W}$ Long), North Haven, Connecticut. Log lies $18 \pm 0.5 \mathrm{ft}$ below surface of tidal marsh, but overlying peat has been compacted, and underlying silt has been faulted, by artificial fill; downthrow on fault, measured as 1 to $2 \mathrm{ft}$, is a minimum figure for displacement of $\log$, which therefore relates to a sealevel at $-16 \mathrm{ft}$ or higher. Coll. and subm. by A. L. Bloom. Comment: one of the samples affected by compaction, rejected by Bloom and Stuiver (1963) in drawing their curve of relative marine submergence.

\section{Plum Bank Creek series, Connecticut}

Peat from a layer of undertermined thickness, occupying a closed depression under estuarine mud, S part of Plum Bank Creek tidal marsh (41 ${ }^{\circ} 15.9^{\prime}$ N Lat, 72 23.4' W Long), Old Saybrook, Connecticut. Coll. 1961 and subm. by A. L. Bloom.

\section{Y-1075. Plum Bank Creek $38 \mathrm{ft} \quad 3500 \pm 130$}

From $37 \mathrm{ft} 10$ in. to $38 \mathrm{ft}$, immediately below base of estuarine mud.

\section{Y-1076. Plum Bank Creek 24 ft}

$3630 \pm 140$

From $24 \mathrm{ft} 3$ in. below surface, 1.5 in. below base of estuarine mud, on flank of depression.

Comment: compaction has evidently lowered both samples; they were rejected by Bloom and Stuiver (1963).

\section{Y-1179. Westport, Connecticut \\ $2710 \pm 90$ \\ 760 в.с.}

Freshwater peat from bottom 3 in. of a bed $3 \mathrm{ft}$ thick, overlain by ca. $7 \mathrm{ft}$ of estuarine mud and salt-marsh peat, Longshore Country Club $\left(41^{\circ} 06^{\prime} \mathrm{N} \mathrm{Lat}\right.$, $73^{\circ} 21.5^{\prime}$ W Long), Westport, Connecticut. Sample dates 10.4 $\pm 0.4 \mathrm{ft}$ of coastal submergence. Coll. and subm. by A. L. Bloom. Comment: sample falls ca. $2 \mathrm{ft}$ below line of sealevel rise established by bottommost samples at Hammock River, Clinton (Bloom and Stuiver, 1963), implying either (a) some displacement by compaction, or (b) a mean carbon age for $3 \mathrm{in}$. of sample that is ca. 300 yr too young.

Y-451 bis. Meriden Airport, Connecticut

$>40,000$

Tamarack wood (id. by W. L. Stern) from 3.5-ft log imbedded in till at base of section of till and silt, $14 \mathrm{ft}$ thick, overlying bedrock, $1.2 \mathrm{mi} \mathrm{S}$ of school in South Meriden (41 $27^{\prime}$ N Lat, $72^{\circ} 48^{\prime} \mathrm{W}$ Long), Wallingford, Connecticut. 
Dated previously (Y-451, Yale III) at 32,000 \pm 2800 . Coll. 1956 and subm. by P. M. Hanshaw, U. S. Geol. Surv., Denver, through R. F. Flint. Comment (R.F.F.) : confirms the infinite dates (>35,000, W-518 and W-519, USGS V) obtained by the Washington laboratory for samples of the same specimen.

\section{Y-923. Broad Brook, Connecticut}

$7380 \pm 160$ 5430 в.с.

Calcareous concretion from a lamina in lacustrine silt and clay (Hartford clay of Flint), $32 \mathrm{ft}$ below top of silt-clay body, W bank of Broad Brook $\left(41^{\circ}\right.$ $55^{\prime} \mathrm{N}$ Lat, $72^{\circ} 33^{\prime} \mathrm{W}$ Long), Broad Brook, Connecticut. Coll. and subm. by R. F. Flint. Comment: measured to test the assumptions that carbonate was deposited from connate lake water soon after deposition, and that $\mathrm{CO}_{2}$ in lake water was in equilibrium with the atmosphere. As the Hartford clay is lateglacial and known to be older than 10,710 B.P. (Y-253, Yale II), the concretion is evidently younger than the inclosing deposit, invalidating the first assumption, and the second assumption is not tested.

\section{Rogers Lake series, Connecticut}

Gyttja from core ROG-2, taken with 2-in. Livingstone sampler in $10 \mathrm{~m}$ of water, center of $\mathrm{S}$ basin of Rogers Lake $\left(41^{\circ} 22^{\prime} \mathrm{N}\right.$ Lat, $72^{\circ} 18^{\prime} \mathrm{W}$ Long), Lyme, Connecticut. Measured as part of a study of sedimentation rates and paleolimnology in a soft-water lake where contribution of $\mathrm{C}^{14}$ deficient ground water should be minimal. Sample depths measured above bottom of each meter of core; small corrections applied afterward are for compaction during extrusion. Coll. 1961 and subm. by Margaret B. Davis, Univ. of Michigan, Ann Arbor, and E. S. Deevey.

\section{Y-947. Rogers 2-20, 19.74 to $19.68 \mathrm{~m}$}

$9740 \pm 160$

From 60 to $65 \mathrm{~cm}$ above bottom of core 2-20.

Y-943. Rogers 2-20, 19.99 to $19.93 \mathrm{~m}$ 7790 в.с.

From 40 to $45 \mathrm{~cm}$ above bottom of core 2-20.

\section{Y-938/39. Rogers 2-20, 20.31 to $20.18 \mathrm{~m}$}

From 15 to $25 \mathrm{~cm}$ above bottom of core 2-20.

\section{Y-936. Rogers 2-20, 20.50 to $20.37 \mathrm{~m}$}

From 0 to $10 \mathrm{~cm}$ above bottom of core 2-20.

\section{Y-958/59. Rogers 2-21, 20.85 to 20.75 m}

From 65 to $75 \mathrm{~cm}$ above bottom of core 2-21.

\section{Y-954/55. Rogers 2-21, 21.10 to $20.95 \mathrm{~m}$}

From 40 to $55 \mathrm{~cm}$ above bottom of core 2-21.

$$
\text { Y-952/53. Rogers 2-21, } 21.30 \text { to } 21.10 \mathrm{~m}
$$

From 20 to $40 \mathrm{~cm}$ above bottom of core 2-21.

$$
\begin{gathered}
9970 \pm 170 \\
\mathbf{8 0 2 0} \text { в.с. } \\
10,910 \pm 180 \\
8960 \text { в.C. }
\end{gathered}
$$

$$
11,470 \pm 160
$$$$
9520 \text { в.c. }
$$

$$
\begin{gathered}
11,760 \pm 180 \\
9810 \text { в.с. }
\end{gathered}
$$

$$
\begin{aligned}
& 13,150 \pm 150 \\
& 11,200 \text { в.с. }
\end{aligned}
$$

$$
13,280 \pm 220
$$$$
\text { 11,330 в.c. }
$$ 


\section{Y-950/51. Rogers 2-21, 21.50 to $21.30 \mathrm{~m}$}

From 0 to $20 \mathrm{~cm}$ above bottom of core $2-21$.

Comment: Rogers Lake, despite its softness, proves to contain appreciable amounts of old carbon from ground water; surface sediments (Y-1261, 1262, this date list) have an average $\mathrm{C}^{14}$ assay of $-100 \%$, or an "age" of $770 \mathrm{yr}$. Dates reported here are calculated from this as zero time, so assuming the carbonate error to have been systematic. The error is smaller here than in mediumhard Linsley Pond, where pre-H-bomb mud has $\delta \mathrm{C}^{14}=-212 \%$ (Y-1182, this date list), and where ca. $10 \%$ of the deep-water $\mathrm{CO}_{2}$ is contributed by carbonates (Deevey and Stuiver, in press). Preliminary estimates of sedimentation rate (Deevey, in press) are not affected by uncertainty as to absolute age; they indicate wide variation within this series, from 1.62 to $13.3 \mathrm{~cm}$ per century. Relation of the variations to changing climate and vegetation is being studied by Margaret B. Davis, as are absolute fallout rates of pollen. Organic deposition was approximately parallel to total deposition, proving that the major variations are not the consequence of massive injection of silt, as by solifluction. Disregarding variations, the overall rate over the first (late-glacial) $4500 \mathrm{yr}$ of the lake's history was about half the postglacial rate, as judged from the fact that the overlying $9.7 \mathrm{~m}$ of sediment accumulated since 9740 B.P. The great age of the deepest samples is noteworthy, as it is consistent with the dates for the pollen sequence at Totoket Bog, in the same district (Leopold, 1956; Deevey, 1958).

\section{Norfolk district series, Virginia-North Carolina}

Wood and peat from significant stratigraphic positions in the vicinity of Norfolk, Virginia, related to a detailed study of Pleistocene geology of the district, supported by Grant 609 (40), Office of Naval Research. Samples were selected to fix time limits for critical stratigraphic units. Subm. by various collectors through R. F. Flint.

\section{Y-1146. Dismal Swamp}

$7670 \pm 60$ 5720 в.c.

Fibrous peat from two cores, $1 \mathrm{~m}$ apart, 3.55 to $3.59 \mathrm{~m}$ depth in core 61 123 and 3.52 to $3.56 \mathrm{~m}$ depth in core 61-118, Dismal Swamp Station DS49 on Jericho Ditch, 3.4 km N of Lake Drummond $\left(36^{\circ} 39^{\prime} 13^{\prime \prime} \mathrm{N}\right.$ Lat, $76^{\circ} 28^{\prime} 45^{\prime \prime}$ W Long). From base of peat, close to transition to underlying clay. Coll. and subm. by D. R. Whitehead, Williams Coll., Williamstown, Massachusetts. Comment: dates inception of the Dismal Swamp Peat.

\section{Y-924. Sandbridge, Virginia}

$730 \pm 70$

\section{A.D. 1220}

Stump of pine (id. by G. Burns), rooted in firm peaty clay, ca. $1 \mathrm{ft}$ below

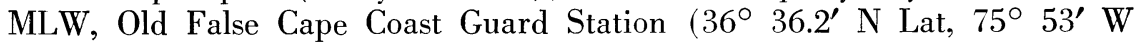
Long), Sandbridge, Virginia. Coll. 1960 by Wyman Harrison, D. Oglesby, and C. S. Sherwood, III; subm. by Harrison, Norfolk Coll. of William and Mary, Norfolk 8, Virginia. Comment (R.Q. Oaks, Jr.) : dates a position of sealevel at least $8 \mathrm{ft}$ below present sealevel. 
Y-1272. Aydlett, North Carolina

Wood from peat exposed in cliff face, alt $2 \mathrm{ft}$, overlying beach sand, overlain by $15 \mathrm{ft}$ of eolian (?) sand, Aydlett ( $36^{\circ} 20^{\prime} \mathrm{N}$ Lat, $75^{\circ} 54^{\prime} \mathrm{W}$ Long), North Carolina. Coll. and subm. by R. Q. Oaks, Jr., Yale Univ. Comment (R.Q. Oaks, Jr.) : peat, noticed first by W. H. Harris, dates youngest of a sequence of barrier bars (Sandbridge $\mathrm{fm}$ ), which are probably of Sangamon age.

\section{Y-1194. Mears Corner, Virginia}

Wood, probably driftwood, alt $5 \mathrm{ft}$ above MSL, $7 \mathrm{ft}$ below ground surface, in section of sand (Kempsville $\mathrm{fm}$ ), overlying shell-rich sand (Norfolk $\mathrm{fm}$ ), overlain by sandy clay (Sandbridge fm), exposed in borrow pit, Mears (Bonneys) Corner $\left(36^{\circ} 47^{\prime} 30^{\prime \prime} \mathrm{N}\right.$ Lat, $76^{\circ} 10^{\prime} 19^{\prime \prime} \mathrm{W}$ Long), S of Kempsville, Virginia. Coll. and subm. by R. Q. Oaks, Jr. Comment (R.Q. Oaks, Jr.) : dates a stratigraphic unit known to be older than Y-1272 (this date list and series).

\section{Y-1271. Benns Church, Virginia}

$>40,000$

Peat, alt ca. $-2 \mathrm{ft}, \mathrm{N}$ side of Muddy Cross Creek, Benns Church $\left(36^{\circ} 55^{\prime}\right.$ $\mathrm{N}$ Lat, $76^{\circ} 35^{\prime} \mathrm{W}$ Long), Isle of Wight County, Virginia. Overlies gray sand overlying Miocene Yorktown fm; peat unit is basal part of a valley fill. Coll. and subm. by J. E. Sanders, Yale Univ. Comment (R.F.F.) : confirms expectation.

\section{Y-1047. Churchland, Virginia}

Taxodium wood from boring, 45 to $48 \mathrm{ft}$ below surface (ca. 26 to $29 \mathrm{ft}$ below MSL), South Street Baptist Church ( $36^{\circ} 51^{\prime} 10^{\prime \prime} \mathrm{N}$ Lat, $76^{\circ} 22^{\prime} 54^{\prime \prime} \mathrm{W}$ Long), Bowers Hill quadrangle, Churchland, Virginia. May be correlative with extensive buried forest at similar altitude that underlies Norfolk, to the E. Coll. 1961 by E. F. Caldwell and Wyman Harrison; subm. by Harrison. Comment (R.F.F.) : date implies that the sample, inferred to have grown not far above sealevel of the time, is not of Wisconsin age. Its latest probable age is late Sangamon.

\section{Y-1102. Zionsville, Indiana}

Wood fragments from section exposed in streamcut in NE $1 / 4$ SE $1 / 4$ SE $1 / 4$ sec. 29, T $17 \mathrm{~N}$, R 2 E (39 $53^{\prime} \mathrm{N}$ Lat, $86^{\circ} 19^{\prime} \mathrm{W}$ Long), Zionsville quadrangle, Indiana. From till immediately above contact of till with underlying silt. Till is overlain by a sequence of gravel and till layers; silt is underlain by dense gray till. Coll. 1959 by Wyman Harrison and others; subm. by Harrison through R. F. Flint. Comment (R.F.F.) : wood fragments from same zone in till gave $>38,000(\mathrm{~W}-814$, USGS V) ; wood fragments at contact of this till with underlying silt, nr Trader's Point, Indiana, were dated at $>37,000$ (W. 578, USGS V). Collector expected a post-Sangamon age for the till. The new dating does not deny that expectation; it merely increases the minimum date by 4000 yr over that of W-814.

\section{B. Minnesota}

\section{Kirchner Marsh series, Minnesota}

Pollen-dated peat and gyttja from Kirchner Marsh, SW 1/4 NE 1/4 sec. 17,

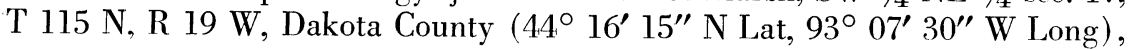


$17 \mathrm{mi} \mathrm{S}$ of Minneapolis, Minnesota. The marsh, an ice-block depression, is situated in the St. Croix moraine of Cary age; during the Mankato sub-age the Des Moines lobe overlapped the St. Croix moraine and advanced to within $4 \mathrm{mi}$ of the marsh, which was then a lake. Pollen stratigraphy was reported by Winter (1962) and is discussed in full by Wright, Winter, and Patten (ms subm. for pub.). Coll. by T. C. Winter and others; subm. by H. E. Wright, Univ. of Minnesota, Minneapolis 14.

\section{Y-1155. Kirchner Marsh $175 \mathrm{~cm}$}

$$
1660 \pm 80
$$
Core 1.

At base of sub-zone of rising pine pollen, $175 \mathrm{~cm}$ depth, in Zone C-c,

\section{Y-1139. Kirchner Marsh $517-523 \mathrm{~cm}$}

$$
\mathbf{5 4 5 0} \pm \mathbf{7 0}
$$
3500 в.c.

At top of Zone C-b (prairie period), at begining of oak-pollen rise, 517 to $523 \mathrm{~cm}$ depth, Core 1.

\section{Y-1140. Kirchner Marsh 777-783 cm}

$7120 \pm 110$

\section{0 в.C.}

At base of Zone C-b (prairie period), at beginning of oak-pollen minimum, 777 to $783 \mathrm{~cm}$ depth, Core 1 .

\section{Y-1141. Kirchner Marsh $982-988 \mathrm{~cm}$}

$10,230 \pm 110$

Near base of Zone B, at sharp birch-pollen maximum, 982 to $988 \mathrm{~cm}$ depth, Core 1 .

Comment: Kirchner Marsh provides a standard pollen diagram for the decidous-forest region of southern Minneosta, and the four $\mathrm{C}^{14}$ dates in its postglacial part are in close agreement with expectation. Correlation with other pollen-dated sections shows, however, that the pollen-zone boundaries are not necessarily synchronous over wide areas of Minnesota. Some discrepancies are noted at Cedar Bog Lake (this date list) $50 \mathrm{mi}$ to the $\mathrm{N}$, and correlation over greater distances, as with Madelia (Jelgersma, 1962; Winter, 1962) at the prairie border in the SW part of the state, or with Weber Lake (Fries, 1962) in the conifer forest in the NE part, is not made easy by the information available so far. The sharp birch-pollen peak seems to be an excellent horizonmarker, now dated at three sites (Kirchner Marsh, 10,230 \pm 110, Y.1141; Cedar Bog Lake, 10,840 \pm 160 , Y-1198, this date list; Weber Lake, 10,550 $\pm 300, \mathrm{~W}-873$, USGS V, and 10,180 \pm 160 , U-176, Uppsala III) ; it also occurs at Madelia but is not closely dated there. As a reflection of the first postglacial immigration of birch woodland, however, it is unlikely to be synchronous at all sites.

\section{Cedar Bog Lake series, Minnesota}

Pollen-dated gyttja from Cedar Bog Lake (= Cedar Creek Bog), NW 1/4

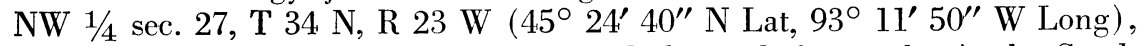
Anoka County, Minnesota. Age of the underlying drift, i.e. the Anoka Sandplain, laid down during retreat of the Grantsburg sub-lobe toward the SW, is considered to be Mankato (Wright and Rubin, 1956; Leighton and Wright, 
1957), partly on evidence of W-466 (11,830 \pm 200 , USGS IV) from a deep sample in this bog. It is the locality of classic investigations by Lindeman (1941) ; a sample from the top of Lindeman's pine-pollen zone was dated 7988 \pm 420 (C-332, Chicago I; Flint and Deevey, 1951). Pollen stratigraphy is being investigated by E. J. Cushing. Coll. by Cushing and others and subm. by Wright.

Y-1196. Cedar Bog C-b/C-c

$$
\begin{aligned}
& 4150 \pm 120 \\
& 2200 \text { в.c. }
\end{aligned}
$$

At boundary of pollen-zones C-b and C-c, 2 10-cm samples ( 1 in. diam) from each of two adjacent cores, 395 to $405 \mathrm{~cm}$ depth in Core B-1 and 408 to $418 \mathrm{~cm}$ depth in Core C-2; correlation of the two cores based on sediment stratigraphy.

\section{Y-1197. Cedar Bog 940-950 cm}

$7880 \pm 120$

5930 в.C.

In dark gyttja layer recording lowest postglacial water level, 940 to 950 cm depth, Core B-6; pollen stratigraphy places it within Zone C-b.

\section{Y-1198. Cedar Bog 1420-1430 cm}

$10,840 \pm 160$

At birch-pollen peak, boundary of Zones A and B, 1420 to $1430 \mathrm{~cm}$ depth, Core CE-10.

Comment: Zone C-b represents the prairie maximum in this region, presently occupied by deciduous forest; its top, in Cedar Bog Lake, appears to be clear, but the date, $4150 \pm 120$ (Y-1196) is appreciably younger than the correlated horizon at Kirchner Marsh $(5450 \pm 70$, Y-1139, this date list). The discrepancy may reflect the difficulty of tracing pollen-stratigraphic boundaries where climatic change was gradual and slight. The bottom of the zone, in Cedar Bog Lake, is even less well marked, and Y-1197 was chosen wthin the zone because it marks a definite lithologic unit; but the date, $7880 \pm 120$, makes it older than the C-a/C-b boundary at Kirchner Marsh (7120 \pm 110 , Y-1140, this date list). On this evidence the date of C-332, $7988 \pm 420$ (Chicago I), which was taken at a stratigraphically lower level, now appears to be ca. $2000 \mathrm{yr}$ too young. The age of the birch-pollen maximum, 10,840 \pm 160 (Y-1198), is in line with others (listed under Kirchner Marsh series), though slightly older.

\section{Imuruk Lake series, Alaska}

$$
\text { C. Alaska }
$$

Silty gyttja from pollen-dated core in Imuruk Lake $\left(65^{\circ} 34^{\prime} \mathrm{N}\right.$ Lat, $163^{\circ}$ $12^{\prime} \mathrm{W}$ Long), Seward Peninsula, Alaska. Arboreal pollen is notably deficient throughout the $8-\mathrm{m}$-long core, indicating that tundra conditions have prevailed in the region throughout the recorded history, which includes the latest dryland episode of the Bering Land Bridge (Colinvaux, in press). Pollen stratigraphy is divisible into 12 zones; their correlation with glacial and interglacial stages, or, alternatively, with substages of the Wisconsin and Holocene, depends on their absolute ages. Full description by Colinvaux is in course of publication. Coll. 1960 and subm. by Paul A. Colinvaux, Duke Univ. (present address: Queen's Univ., Belfast, N Ireland). 


\section{Y-1144. Imuruk 0.35 m}

$12,355 \pm 160$

10,405 в.c.

At base of high-Alnus (latest) Zone L. Comment: unexpectedly great age of this sample, supposedly near top of a tripartite postglacial sequence, is approximately confirmed by date of 13,250 \pm 700 (I-588, Isotopes, Inc., unpublished) for a slightly deeper sample $(0.5 \mathrm{~m})$.

Y-1142. Imuruk $1.2 \mathrm{~m}$

$>\mathbf{3 4 , 5 0 0}$

At middle of Zone J, where Betula pollen begins its latest rise; supposedly at base of tripartite postglacial sequence. Comment: evidently sample is early W'isconsin or older.

Y-1143. Imuruk $2.6 \mathrm{~m}$ $>37,000$

At middle of Zone I, where arboreal pollen (Betula, Alnus, Picea) is relatively high. Comment: in light of the date, the high-AP zone, formerly thought to be of Alleröd and/or Bölling age, is most reasonably interpreted as either Sangamon or a mid-Wisconsin interstadial. Older episodes of the same sort, recorded between 1.2 and $8 \mathrm{~m}$, are clearly beyond the reach of $\mathrm{C}^{14}$ dating. An Isotopes, Inc. date, $21,700 \pm 2000$ (I-415, unpublished) for the $7.5-\mathrm{m}$ level, is shown to be more probably infinite by this sample and Y-1142.

\section{Anaktuvuk Pass series (continued), Alaska}

Wood and organic matter from deposits related to glaciation in the Anaktuvuk Pass district, Alaska. Coll. 1961 and subm. by Stephen C. Porter, Univ. of Washington, Seattle 5. A full account, by Porter, has been subm. for publication.

\section{Y-1082. Summit Lake $14 \mathrm{ft}$}

Organic matter, $14 \mathrm{ft}$ depth, from perennially frozen lacustrine silt in an Eskimo cellar beside Summit (Eleanor) Lake $\left(68^{\circ} 09^{\prime} \mathrm{N}\right.$ Lat, $151^{\circ} 43^{\prime} \mathrm{W}$ Long). Silt was deposited in a small temporary lake marginal to wasting ice during a retreatal phase of the Echooka glaciation. A sample from the same unit, at $9 \mathrm{ft}$ depth below surface, was dated $6260 \pm 160$ (Y-770, Yale VI). Comment (S.C.P.) : provides a minimum age for a late readvance during the Itkillik glaciation in the Anaktuvuk Valley.

\section{Y-1083. Anaktuvuk River}

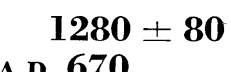

Peat and willow twigs from layer of fine sand near middle of an 8-ft section of stratified sand and gravel in cutbank of Anaktuvuk River, ca. $3 \mathrm{mi} \mathrm{S}$ of Banded Mountain ( $68^{\circ} 32^{\prime} \mathrm{N}$ Lat, $151^{\circ} 15^{\prime} \mathrm{W}$ Long). Comment (S.C.P.) : sample gives maximum age for cutting of lowest terrace in outwash from a moraine that represents a readvance of the Itkillik ice intermediate between those dated by Y-1084 and Y-1082.

\section{Y-1084. Anayaknaurak Creek}

$13,270 \pm 160$

1I,320 в.c.

Willow twigs from yellowish lacustrine sand overlying gravel (outwash), $7 \mathrm{ft}$ thick, and stony till, $15 \mathrm{ft}$ thick, overlain by till and outwash, cutbank on 
Anaktuvuk River $0.5 \mathrm{mi}$ N of mouth of Anayaknaurak Creek ( $68^{\circ} 31^{\prime} \mathrm{N}$ Lat, $151^{\circ} 17^{\prime} \mathrm{W}$ Long). Comment (S.C.P.) : dates a glacial readvance during the Itkillik glaciation along Anaktuvuk River.

\section{Y-1085. Anayaknaurak Creek, outwash}

$5180 \pm 70$ 3230 в.с.

Organic matter underlying 15 in. of pebble gravel and 18 in. of till (?), overlying $10 \mathrm{ft}$ of cobble gravel, cutbank of Anaktuvuk River nr mouth of Anayaknaurak Creek (68 $30^{\prime} \mathrm{N}$ Lat, $151^{\circ} 18^{\prime} \mathrm{W}$ Long). Comment (S.C.P.) : sample description was erroneous; no till is present in section. Sample gives minimum date for beginning of dissection of outwash fan associated with a glacial readvance intermediate between those dated by Y-1082 and Y-1084.

\section{Y-1086. Shainin Lake $+\mathbf{5} \mathbf{f t}$}

$$
\begin{array}{r}
1530 \\
\text { A.D. } 420
\end{array}
$$

Willow twigs from stratified deltaic sand, $\mathrm{S}$ end of Shainin Lake $\left(68^{\circ} 20^{\prime}\right.$ $\mathrm{N}$ Lat, $151^{\circ} 03^{\prime} \mathrm{W}$ Long), $5 \mathrm{ft}$ above base of cutbank $\mathrm{nr}$ mouth of Alapah Creek. Delta was built into a lake dammed by ice of the Echooka glaciation that occupied the basin now filled by Shainin Lake. Comment: see Y-1087.

\section{Y-1087. Shainin Lake $+9 \mathbf{f t}$}

$$
2750 \pm 70
$$

800 в.c.

Willow twigs from same locality and unit as Y-1086, $9 \mathrm{ft}$ above base of cutbank. Comment (S.C.P.) : delta, interpreted as glacial, is clearly younger than the glacial advance dated at $7240 \pm 100$ by Y-1082. The two dates, Y-1086 and Y-1087, are in reverse of stratigraphic order, possibly by interchange of their numbers, but both are reasonable. The older is similar to that of Y-771 $(2830 \pm 120$, Yale VI), which dates the maximum stand of the Alapah Mountain glaciation, and to that of Y.871 $(2760 \pm 150$, Yale VI) on similar sediment in the Anaktuvuk Valley. The younger is similar to that of Y.872 (1120 \pm 90 , Yale VI) in the Anaktuvuk Valley. The implication is that sedimentation in both valleys was more or less continuous from ca. 3000 to ca. 1000 B.P.

\section{Guatemala}

\section{Laguna de Petenxil series (continued), Guatemala}

Gyttja from a core under ca. $4 \mathrm{~m}$ of water, Laguna de Petenxil $\left(16^{\circ} 55^{\prime}\right.$ $\mathrm{N}$ Lat, $89^{\circ} 50^{\prime} \mathrm{W}$ Long), the first lake $\mathrm{E}$ of Flores in an $\mathrm{E}-\mathrm{W}$ chain of lakes, Dept. of El Peten, Guatemala. Description is given in Yale VI, where the geographic position is wrongly reported. Subm. by G. E. Hutchinson and Ursula Cowgill, Yale Univ.

\section{Y-1289. Petenxil II, 86-87, $90-91 \mathrm{~cm}$}
$1040 \pm 200$ A.D. 910 K.

Core II, 86 to 87 and 90 to $91 \mathrm{~cm}$ depth; small maximum in exchangeable

\section{Y-1286. Petenxil II, 161-163 cm}

$2050 \pm 350$

100 в.C.

Core II, 161 to $163 \mathrm{~cm}$ depth; greatest maximum in exchangeable K. 


\section{Y-1285. Petenxil II, 250-251 cm \\ $3990 \pm 160$ \\ 2040 в.c.}

K.

Bottomof Core II, 250 to $251 \mathrm{~cm}$ depth; small maximum in exchangeable

Comment (U.C.) : first two sections of Core II are equivalent to the whole of Core III (Yale VI) in time. The rate of sedimentation is the same for the period $2170 \pm 85$ to $1305 \pm 140$ B.P., but there is an increase from $0.09 \mathrm{~cm}$ per yr in the top portion of Core III that is not reflected in Core II.

\section{Molokai series, Hawaii}

\section{E. Hawaii}

Peat from bog at Pepeopae $\left(21^{\circ} 07^{\prime} 30^{\prime \prime} \mathrm{N}\right.$ Lat, $156^{\circ} 55^{\prime} \mathrm{W}$ Long), alt $1214 \mathrm{~m}$, ca. $22 \mathrm{~km}$ E of Molokai Airport, Molokai Island. Borings were made in the vicinity of Localities 1 and 9 as shown by Selling (1948, p. 61). Pollen stratigraphy is under investigation to supplement that by Selling. Coll. 1961 by Lucy Cranwell Smith, Dick Shutler, Jr., and Calvin Heusser; subm. by Heusser, Amer. Geog. Soc., New York 32, N. Y.

\section{Y-1103. Pepeopae $1 \mathrm{~m}$}

From $1 \mathrm{~m}$ depth, Selling's Localities 1 and 2.

\section{Y-1104. Pepeopae $2 \mathrm{~m}$}

$2600 \pm 180$

650 в.с.

From $2 \mathrm{~m}$ depth, Selling's Localities 1 and 2.

$6100 \pm 180$

4150 в.c.

Y-1106. Pepeopae $3.2 \mathrm{~m}$

$28,100 \pm 2000$

26,150 в.с.

From 3.3 to $3.4 \mathrm{~m}$ depth, Locality 1 and $3.2 \mathrm{~m}$ depth, Locality 2 .

Comment: Selling (1948) established three zones in his Hawaiian pollen sections, Periods I and III being drier and probably cooler than Period II; correlation with Europe and the Americas suggested that I was late-glacial, II hypsithermal, and III post-hypsithermal. The dates support this interpretation. The published pollen diagram (Selling, 1948, pl. 24) indicates that the bottom few $\mathrm{cm}$ may belong to Period I, though Selling did not make this assignment; the date of Y-1106 places the sample farther back in the Wisconsin glacial age than was expected. Y-1104 lies well up in the hypsithermal zone, and Y-1103 lies at the transition to Period III. Both dates are as expected, and the SubAtlantic age of the zone boundary is in striking agreement with Selling's correlation.

\section{F. Australia}

\section{Kosciusko series, New South Wales}

The Kosciusko area contains a variety of frost soils and minor landscape features believed to have originated during periglacial conditions. One such group of features, solifluction lobes and terraces, are being studied in detail. The lobes and terraces occur in stepwise arrangement on wind-exposed, welldrained slopes between $5^{\circ}$ and $30^{\circ}$, mainly on metasediments, in the alpine tract above ca. $6500 \mathrm{ft}$. Present vegetation is fjaeldmark (dwarf open heath). 
There are no indications of soil activity at present. In section, lobes and terraces show up to $2 \mathrm{ft}$ of stony soil, with abundant fines and small stones, overlying a stony layer (frost debris without fines) that rests abruptly on bedrock. In places a relatively organic stone-free lens occurs between the stony upper soil and the stony layer, from which small carbonized fragments of fjaeldmark shrubs can be extracted. Some of these were coll. by A. B. Costin and B. Thom, C.S.I.R.O. Div. of Plant Industry, Canberra, and subm. by Costin.

\section{Y-1090. Kosciusko 1}

Wood fragments, mainly Epacris petrophila, from nr base of terrace ( $36^{\circ} 25^{\prime}$ S Lat, $148^{\circ} 17^{\prime}$ E Long), between Mount Northcote and Mount Lee.

\section{Y-1091. Kosciusko 3}

$120 \pm 130$

A.D. 1830

Same locality as Y-1090, but from nr base of an adjacent, lower terrace.

\section{Y-1092. Kosciusko 5}

$2910 \pm 130$

Wood fragments from base of terrace $\left(36^{\circ} 26^{\prime} \mathrm{S}\right.$ Lat, $148^{\circ} 17^{\prime} \mathrm{E}$ Long $)$, Mount Northcote.

\section{Y-1093. Kosciusko 6}

From base of same terrace as Y-1092, $41 / 2 \mathrm{ft}$ farther downslope.

\section{Y-1094. Kosciusko 8}

$2860 \pm 160$

From base of a terrace nr Y-1092 and Y-1093.

\section{Y-1095. Kosciusko 9}

910 в.с.

From base of same terrace as Y-1094, a few feet farther downslope.

\section{Y-1096. Kosciusko 10}

$$
1540 \pm 160
$$

A.D. 410

From buried layer in same terrace as Y-1094 and Y-1095, at slightly greater depth.

Comment (A.B.C.) : the principal inference from the dates, most of which lie between 2250 and 3000 B.P., is that solifluction has been active through a time known elsewhere as the Little Ice Age. In the most exposed areas between Mount Northcote and Mount Lee, activity appears to have continued at least up till the 18th century A.D. The stony layer beneath the organic lenses indicates a more severe period of frost action prior to the oldest dated episode of solifluction (ca. 1000 в.c.) ; this may well have occurred during a glacial age. The rate of downslope movement of the lobe and terrace features appears to have been fairly rapid; at least it was too fast to be detected by $\mathrm{C}^{14}$ dating within a single body of material, as shown by the identity of dates for one pair (Y-1092 and Y-1093) and reversal of ages within another (Y-1094 and Y. 1095). Fuller accounts of solifluction and other periglacial features in the Kosciusko area are being prepared. 


\section{Murrumbidgee Plain series, New South Wales}

Transported wood samples in alluvium, coll. by Trevor Langford-Smith as part of a study of geomorphic history of a sector of Australia's inland plains (ca. $34^{\circ}$ to $36^{\circ} \mathrm{S} \mathrm{Lat,} 143^{\circ}$ to $147^{\circ} \mathrm{E}$ Long) (Langford-Smith, 1960). The extensive, nearly flat alluvial plain, bordering the Eastern Highlands on the W and $\mathrm{N}$, is being dissected by through-flowing rivers including the Murrumbidgee, a major tributary of the Murray, but was obviously deposited by older rivers, some of whose courses can still be traced and shown to be unrelated to the present drainage pattern. A network of distributary channels, implying an enormous subaerial delta or series of coalescent deltas, emerges from reconnaissance mapping; only its point of debouchment from the mountain front, $\mathrm{nr}$ Narrandera, is related to the present courses of the Murrumbidgee. Most of the prior watercourses are now dry throughout their length, and the region is without clearly defined surface drainage. The latest series of distributaries is believed to have been active in Wisconsin time and to have carried at least some water two or three times since then; their maximum discharge, as measured by wavelengths of meanders, implies a markedly pluvial climate in the middle to late Wisconsin. Time relations within the series and between the latest and older generations of prior watercourses are problematic. Subm. by LangfordSmith, Univ. of Sydney.

\section{Y-861. Darlington Point, 1A}

$$
\begin{gathered}
11,140 \pm 160 \\
9190 \text { в.c. }
\end{gathered}
$$

From levee bank, $2.5 \mathrm{ft}$ below present surface, accompanied by freshwater shells $\left(35^{\circ} 06^{\prime} \mathrm{S}\right.$ Lat, $146^{\circ} 00^{\prime} \mathrm{E}$ Long). Possibly related to an aboriginal midden.

\section{Y-862. $4 \mathrm{mi}$ NW of Darlington Point, 1B}

$$
\mathbf{2 4 8 0} \pm \mathbf{8 0}
$$

$$
\mathbf{5 3 0} \pm \text { B.C. }
$$

From levee bank, ca. $3 \mathrm{ft}$ below present surface $\left(35^{\circ} 00^{\prime} \mathrm{S}\right.$ Lat, $145^{\circ} 58^{\prime}$ E Long), 4 mi downstream from Y-861 in same prior stream.

\section{Y-864. $5 \mathrm{mi}$ W of Wilbriggie, 1C-ii}

$4700 \pm 80$

2850 в.c.

From pit in stream bed, part of cutoff and therefore possibly older than the latest prior-stream alluvium here ( $34^{\circ} 54^{\prime} \mathrm{S}$ Lat, $145^{\circ} 56^{\prime} \mathrm{E}$ Long), ca. 8 mi downstream from Y-862 in same prior stream. Part of deposit of driftwood, definitely not roots, $2 \mathrm{ft}$ below present surface.

\section{Y-865. Morundah Road, 2}

$$
4090 \pm 90
$$

2140 в.c.

From bed of prior stream, ca. $3 \mathrm{ft}$ below surface, Morundah Road, $6 \mathrm{mi} \mathrm{S}$ of Sturt Highway ( $34^{\circ} 40^{\prime} \mathrm{S}$ Lat, $146^{\circ} 00^{\prime}$ E Long).

\section{Y-867. Colleambally Sand Quarry, 4}

From current-bedded sand, 12 to $15 \mathrm{ft}$ below present surface, Colleambally Sand Quarry, $6 \mathrm{mi}$ S of Sturt Highway ( $34^{\circ} 45^{\prime} \mathrm{S}$ Lat, $146^{\circ} 16^{\prime} \mathrm{E}$ Long); in hed of prior stream considered on geomorphic evidence to be older than no. 1 (Y-861, 862, 864). 
Y-868. Myrtlebank Station, Lake Cowal, 5

$19,270 \pm 520$

17,320 в.с.

From bed of prior stream in another system $\left(33^{\circ} 35^{\prime} \mathrm{S}\right.$ Lat, $147^{\circ} 35^{\prime} \mathrm{E}$ Long), $17 \mathrm{ft}$ below present surface.

\section{Y-869. Ca. 6 mi SW of Jemalong Weir, $6 \quad 300 \pm 70$ \\ A.D. 1650}

From bed of same prior stream as Y-868, ca. 20 mi upstream $\left(33^{\circ} 28^{\prime} \mathrm{S}\right.$ Lat, $147^{\circ} 45^{\prime} \mathrm{E}$ Long), $1.5 \mathrm{ft}$ below surface, but not certainly part of alluvium. Comment: sample may be part of a modern root, and is rejected as dating alluvium at this locality.

\section{Y-870. Warren-Gulargambone Road, 7}

$$
\begin{array}{r}
1430 \\
\text { A.D. } 520
\end{array}
$$

From levee of prior stream in another system, $150 \mathrm{mi} \mathrm{N}$ of Y-868 $\left(31^{\circ}\right.$ $30^{\prime} \mathrm{S} \mathrm{Lat}, 148^{\circ} 00^{\prime} \mathrm{E}$ Long), ca. $1.5 \mathrm{ft}$ below original surface (before recent erosion).

Comment: as suspected, the latest series of distributaries was active through much or all of Wisconsin time, and continued to carry water in at least two widely separated places until a few hundred or thousand years ago; renewed activity after Australia's Great Arid Period is not ruled out and is rather favored by the clustering of dates into an old group, 11,000 yr or older, and a younger group, $4700 \mathrm{yr}$ or younger. Within the series as a whole the time relations are too complex to be settled by so small a set of $\mathrm{C}^{14}$ dates; the geomorphic evidence of youthfulness is not entirely trustworthy, especially when comparisons are made over long distances. In the same prior stream, $\mathrm{nr}$ Darlington Point, N.S.W., Y-864 is slightly older than Y-862, as expected, but the date of Y-868, nr Lake Cowal, N.S.W., in a different system, proves it to be at least in part older than stream no. 1 , in the Darlington Point district. A summary of the problem is given by Langford-Smith (1962); a fuller account is in preparation but is awaiting more field work and dating.

\section{G. South Africa}

\section{Y-468. Sedgefield, Knysna Division, $S$ Africa $\quad 37,700 \pm 2000$ \\ 35,750 в.c.}

Marine shells from a beach ca. $4 \mathrm{~m}$ above sealevel $(4 \mathrm{~m}$ above top of marine layer at Groenvlei, which was bracketed between dates of $6870 \pm 160$, Y-466, and $1905 \pm 60$, Y-467; Yale IV); buried below a flat sandy plain, believed to be formed subaerially whose surface forms a terrace at Sedgefield ( $34^{\circ} 01^{\prime} \mathrm{S}$ Lat, $22^{\circ} 48^{\prime} \mathrm{E}$ Long), $2 \mathrm{mi} \mathrm{W}$ of Groenvlei and ca. $2 \mathrm{mi}$ inland from the present coast. Upper sandy portion of section contains a red cemented band, thought to be part of a fossil soil and postdating the shells; shells include Calliostoma fultoni, not now living $\mathrm{S}$ of Delagoa Bay, $8^{\circ}$ of latitude farther $\mathrm{N}$, and Cerithium kochi, an Indo-Pacific species of similar implication, though still found at Algoa Bay, ca. $180 \mathrm{mi} \mathrm{E}$ and $1^{\circ}$ of latitude $\mathrm{N}$ of Sedgefield. Coll. 1956 and subm. by A. R. H. Martin, Univ. of Sydney, N.S.W., Australia. Comment: shell bed is thought to belong to an older, higher sealevel than that recorded at Groenvlei (Martin, in press). Calliostoma fultoni is recorded from 
a similar beach at Klein Brak River, $40 \mathrm{mi}$ W, where it was regarded as evidence of a postglacial hypsithermal interval (Krige, 1927), or as Last Interglacial (Maarleveld and van der Hammen, 1959). Older, higher marine features in the district, recording a sealevel at least 7 or $8 \mathrm{~m}$ above the present one, belong to a group commonly thought to be of last interglacial (Monastirian II) age. Features at 4 to $5 \mathrm{~m}$ above present sealevel, including the dated beach at Sedgefield, were ascribed by Krige to "a resting stage in the last emergence," and may belong to the Epimonastirian of Zeuner, which may date from the interval between Early and Main Würm. The date, and the geomorphic evidence of youthfulness, favor such an assignment, but the climatic implication of the shells (sea-surface temperatures ca. $5^{\circ} \mathrm{C}$ higher than today's) does not. A postglacial date is clearly ruled out, and there is no evidence of a postglacial sealevel more than $1.5 \mathrm{~m}$ above the present one in the Knysna district. The possibility of slight contamination of the shells by modern (atmospheric) $\mathrm{C}^{14}$, always present when very old carbonate is used for dating, makes it impossible to be sure that the Sedgefield deposit is not beyond the limit of $\mathrm{C}^{14}$ dating, and therefore probably of last interglacial age; but the shells were not exposed to air until collection, and contamination is not particularly likely.

\section{H. Iran}

\section{Y-1160. Lake Zeribar, Iran, $16.25 \mathrm{~m}$}

$$
\begin{aligned}
& 14,800 \pm 300 \\
& 12,850 \text { в.с. }
\end{aligned}
$$

Carbonate fraction of calcareous silty gyttja, Core I-12, $16.25 \mathrm{~m}$ depth, Lake Zeribar, Merivan ( $35^{\circ} 31^{\prime} \mathrm{N}$ Lat, $46^{\circ} 07^{\prime}$ E Long), Iran. Pollen stratigraphy reported by van Zeist and Wright (1963); chemical analysis reported by Hutchinson and Cowgill (1963). A sample at a stratigraphically higher level in a different core, I-13, was dated $5460 \pm 120$ (Y-934, Yale VII, p. 255; the sample no. was omitted by mistake). Coll. 1960, as part of Oriental Inst. Exped., by H. E. Wright, Jr., and associates; subm. 1962, after chemical sampling, by G. E. Hutchinson, Yale Univ. Comment: sample falls $\mathrm{nr}$ top of Zone A, a high-chenopodiaceous-pollen zone, interpreted as cold and dry, at a maximum of Artemisia pollen. The implication, that the transition from cold to warm climate occurred at ca. 13,000 B.P., is elaborated by van Zeist and Wright. Zone A sediments are the most calcareous in this core; Hutchinson and Cowgill consider that this implies lack of an outlet, at least for considerable periods, and confirms the dry climate as inferred from pollen. Other samples from the same core contained too little carbon, either organic or inorganic, for dating.

\section{ARCHAEOLOGIC SAMPLES}

\section{A. Northeastern United States}

\section{Y.933. St. Jones River site, Delaware}

$$
2330 \pm 80
$$$$
380 \text { в.C. }
$$

Charcoal from the St. Jones River site $\left(39^{\circ} 10^{\prime} \mathrm{N}\right.$ Lat, $75^{\circ} 25^{\prime} \mathrm{W}$ Long $)$, Lebanon, Delaware. Found in a pit with Adena burials. Coll. August 1960 by Leon de Valinger; subm. by D. W. Dragoo, Carnegie Mus., Pittsburgh, Pennsylvania. Comment: comparable to the oldest of three dates previously obtained 
at the West River site for the eastern dispersal of Adena: 75 в.c. (M-418, Michigan I; see also Ritchie and Dragoo, 1960).

Y-1168. Wapanucket No. 8 site, Massachusetts

$3910 \pm 100$

1960 в.с.

Charcoal from Feature 32 at the Wapanucket No. 8 site $\left(41^{\circ} 52^{\prime} 30^{\prime \prime} \mathrm{N}\right.$ Lat, $70^{\circ} 52^{\prime} 30^{\prime \prime} \mathrm{W}$ Long), on the north shore of Assawompsett Lake in Middleboro, Plymouth County, Massachusetts. Coll. August 1960 by Maurice Robbins; subm. by G. A. Agogino, Boston College. Comment: Wapanucket No. 8 site seems to contain two components, one Paleo-Indian and the other Archaic, though they are not separated stratigraphically. This date evidently pertains to the Archaic occupation, since it agrees with three dates previously obtained from the Wapanucket No. 6 site, which is Late Archaic: 2300 B.c. (M-764), 2370 в.c. (W-363), and 2350 в.c. (M-969) . (Robbins, 1959; Michigan IV.)

\section{Y-1157. Hartland, Vermont}

$$
2750 \pm 80
$$
Sumner Falls $\left(43^{\circ} 32^{\prime} \mathrm{N}\right.$ Lat, $72^{\circ} 23^{\prime} \mathrm{W}$ Long), on the Connecticut River, Hartland, Vermont. Coll. 1952 and subm. by H. R. Sargent, Claremont, N. H. Comment: associated with an Archaic deposit, underlying a ceramic occupation. Date is at the top of the range for this type of culture (see preceding and following dates).

\section{Y-1169. Bent site, New York}

$3880 \pm 100$

Charcoal from Feature 12 in Section, E10S10, Bent site (Ams 73), Schenectady County, New York $\left(42^{\circ} 51^{\prime} \mathrm{N}\right.$ Lat, $74^{\circ} \mathrm{l}^{\prime} \mathrm{W}$ Long). Coll. May 1961 by R. E. Funk; subm. June 1962 by W. A. Ritchie, New York State Mus. and Sci. Service, Albany. Comment (W.A.R.) : feature was a hearth, 29 in. below the present surface, which contained, besides the charcoal and burned stones, a Normanskill-type projectile point, the characteristic type of the newly defined River focus, Late Archaic period, of which this is the largest known station.

\section{Y-1170. Snook Kill site, New York}

$3420 \pm 100$

Charcoal from Feature 4, a fire pit, 32 in. deep in the Snook Kill site (Scv 19-2), Saratoga County, New York $\left(43^{\circ} 13^{\prime} 42^{\prime \prime}\right.$ N Lat, $73^{\circ} 35^{\prime} 36^{\prime \prime} \mathrm{W}$ Long). Coll. May 1960 by W. H. Rice; subm. June 1962 by W. A. Ritchie. Comment (W.A.R.) : Material came from basal 8 in. of pit, which contained no artifacts. Pit is believed to pertain to the Snook Hill focus, Late Archaic period (Ritchie, 1958, p. 91-98).

\section{Y-1171. Morrow site, New York}

Charcoal from a cremation in situ on the Marrow site, Honeoye, Ontario County, New York $\left(42^{\circ} 47^{\prime} \mathrm{N}\right.$ Lat, $77^{\circ} 30^{\prime} \mathrm{W}$ Long $)$. Depth ca. 30 in. from the surface. Coll. October 1956 and subm. June 1962 by W. A. Ritchie. Comment (W.A.R.) : this feature, Burial 1, contained grave goods typical of the Meado- 
wood focus (formerly termed the early Point Peninsula culture), Early Woodland period.

\section{Y-1172. Wickham site, New York}

$$
1210 \pm 100
$$

A.D. 740

Charcoal from the Wickham site (Sry 1), Section 2, at Brewerton, Oswego County, New York $\left(43^{\circ} 13^{\prime} 58^{\prime \prime}\right.$ N Lat, 76 $08^{\prime} 31^{\prime \prime}$ W Long). From depth of 19 in. in stratified midden deposits. Coll. 1950 and subm. June 1962 by W. A. Ritchie. Comment (W.A.R.) : pertains to the late Point Peninsula culture, late Middle Woodland period (Ritchie, 1946).

\section{Y-1173. Maxon-Derby site, New York \\ $850 \pm 100$}

Charcoal from large hearth, Feature 38, in Section E50S20, Maxon-Derby site (Bwv B-3), Onondaga County, New York $\left(43^{\circ} 03^{\prime} 42^{\prime \prime} \mathrm{N}\right.$ Lat, $76^{\circ} 26^{\prime} 46^{\prime \prime}$ W Long). Coll. August 1960 and subm. June 1962 by W. A. Ritchie. Comment (W.A.R.) : this is a large village site of an early phase of the Owasco culture, Late Woodland period.

\section{Y-1174. Bates site, New York}

$760 \pm 100$

Combined charcoal from Features 1A, B and 80, Bates site (Grn 1), $2^{1 / 4}$ $\mathrm{mi} \mathrm{S}$ of Greene, Chenango County, New York $\left(42^{\circ} 17^{\prime} 50^{\prime \prime} \mathrm{N} \mathrm{Lat}, 75^{\circ} 47^{\prime} 42^{\prime \prime}\right.$ W Long). Feature 1 A, B (Section W10N100) consisted of two overlapping storage pits, 25 and $32 \mathrm{in}$. deep respectively. It contained much carbonized organic material, pottery, and other artifacts. Sample coll. from it July 1957 and subm. June 1962 by W. A. Ritchie. Feature 80 (Section EON110) was a large storage pit, 29 in. deep. Charcoal found in basal 8 in., together with restorable pot and other artifacts. Coll. August 1958 and subm. June 1962 by W. A. Ritchie. Comment (W.A.R.) : a single component site of a middle phase of the Owasco culture, Late Woodland period.

\section{B. Middle America}

\section{Y-1149. Porrúa manuscript}

Portion of mammal skin, painted with hieroglyphs of Maya style, provenience not known; a facsimile edition has been published (Librería de Manuel Porrúa, 1957). Subm. by Manuel Porrúa, Apdo. Post. 14470, México 1, México. Comment: although $\mathrm{C}^{14}$ dating is too full of small uncertainties to be successfully aplied to objects so young, the date obtained makes it very unlikely that this document is a pre-Conquest survival.

\section{Salinas La Blanca series, Guatemala}

Salinas La Blanca $\left(14^{\circ} 30^{\prime} \mathrm{N}\right.$ Lat, $92^{\circ} 10^{\prime} \mathrm{W}$ Long), is a small village site on the $\mathrm{E}$ bank of the Naranjo River, in the Department of San Marcos, Guatemala; it is not far from the village of Ocós, and only $13 / 4 \mathrm{~km}$ from the Pacific Ocean. The site consists of two broad, low mounds built up from refuse deposits. Excavations were confined to two contiguous cuts in Mound 1, which had been partly carried away by the river; sterile deposits were reached at a 
depth of $6.5 \mathrm{~m}$. The lowermost $4.5 \mathrm{~m}$ of the mound produced materials of a newly defined culture, the Cuadros phase, characterized by a predominance of neckless, globular jars, by a lack of figurines, and by an economy based in part upon maize farming and in part upon the collection of fauna in the estuaries and mangrove forests. Mineralized cobs found in Cuadros refuse are the oldest specimens of maize yet found in Guatemala. Cuadros is believed to predate the Ocós culture, previously found at La Victoria in the same region, but the evidence is not conclusive. Samples coll. 1962 by M. D. Coe and K. V. Flannery under the Inst. for Andean Research program "Interrelationships of New World Cultures;" subm. by M. D. Coe.

\section{Y-1150. Cuadros phase}

$2928 \pm 105$

978 в.C.

Charcoal from small hearth in northeast corner of Cut 2, 3.38 m below datum in Level $0(3.20-3.40 \mathrm{~m})$. Comment (M.D.C.) : should be late in the Cuadros phase.

\section{Y-1151. Cuadros phase}

Charcoal from hearth in northeast quadrant of Cut 2, $4.50 \mathrm{~m}$ below datum in Level U (4.40-4.60 m). Comment (M.D.C.) : should be older than Y-1150.

\section{Y-1154. Cuadros phase}

$2878 \pm 105$

Charcoal from refuse layer in Cut 1, Level BB (5.80-6.00 m). Comment (M.D.C.) : sample is early in the Cuadros phase.

\section{Y-1166. Cuadros phase}

$2764 \pm 90$

Sample probably consisted entirely of charred bone; it dissolved completely in an alkali solution. The alkali precipitate has been dated. From hearth, northwest quadrant of Cut 1, Level CC $(6.00-6.20 \mathrm{~m})$. Comment (M.D.C.) : this should be the oldest sample in the series, lying just above sterile deposits and immediately above the water table. All of the above dates are not inconsistent with each other, considering the statistical error, but are somewhat later than expected.

\section{Y-1167. Río Naranjo site}

$\mathbf{2 7 4 0} \pm \mathbf{7 0}$

790 в.с.

Charcoal extracted from hearth in face of mound cut by the Naranjo River, lying approximately halfway between Salinas La Blanca and the sea, near Ocós, San Marcos, Guatemala. Coll. 1962 by M. D. Coe and K. V. Flannery; subm. by M. D. Coe. Comment (M.D.C.) : cut face of mound produced abundant ceramics of the Conchas phase, and thus should date the Middle Formative period in this part of the Pacific Coast of Guatemala, previously estimated as 800-300 в.C. It should postdate the Cuadros phase, probably by more than a century.

\section{Nicaragua series}

Charcoal samples from the Isthmus of Rivas and Ometepe Island in Lake Nicaragua $\left(11^{\circ} 30^{\prime} \mathrm{N}\right.$ Lat, $85^{\circ} 30^{\prime} \mathrm{W}$ Long), Department of Grenada, 
Nicaragua. Coll. 1961 by A. H. Norweb; subm. by G. R. Willey, Peabody Mus. of Archaeol. and Ethnol., Harvard Univ., Cambridge, Mass. Like the preceding Guatemala series, this was a project of the Inst. for Andean Research program "Interrelationships of New World Cultures."

\section{Y-1122. Rivas, Gr-5, $195 \mathrm{~cm}$}

$1380 \pm 70$

A.D. 570

Charcoal from Cut 2 in the Ayala site (Gr-5) on the Isthmus of Rivas, depth of $195 \mathrm{~cm}$. Comment (G.R.W.) : dates the beginning of the Santa Isabel phase, probably on the line between the Early Polychrome A and B periods.

\section{Y-1124. Rivas, Gr-5, $285 \mathrm{~cm}$}

$1390 \pm 100$

Charcoal from Cut 2 in the Ayala site (Gr-5) on the Isthmus of Rivas, depth of $285 \mathrm{~cm}$. Comment (G.R.W.) : San Jorge phase, probably in the upper range of the Zoned Bichrome period. Should be earlier than Y-1122.

\section{Y-1125. Ometepe Island, Ri-7}

$1170 \pm 120$

A.D. 780

Charcoal from Cut 2 in the Cruz site (Ri-7) on Ometepe Island ca. $500 \mathrm{~m}$ S of Puerto Gracia, depth of $260 \mathrm{~cm}$. Comment (G.R.W.) : dates the end of the Santa Isabel phase, on the line between the Early Polychrome B and Middle Polychrome periods.

General comment: these determinations agree well with the $\mathrm{C}^{14}$ dates previously obtained for the nearby province of Guanacaste, Costa Rica (Yale VI). They also confirm the sequence of periods worked out by M. D. Coe and C. F. Baudez for northwestern Costa Rica (Coe, 1962, Fig. 3).

\section{Northern South America}

\section{Y-927. La Pitía, Venezuela}

$$
\begin{array}{r}
1880 \\
\text { A.D. } 70
\end{array}
$$

Charcoal from Section SS-110, depth of $1.5 \mathrm{~m}$ in the shell heap of La Pitía ( $11^{\circ} 13^{\prime} \mathrm{N}$ Lat, $71^{\circ} 57^{\prime} \mathrm{W}$ Long), near Paraguaipoa, state of Zulia, Venezuela. Associated with culture of the Hokomo phase dated in Period II of the Cruxent-Rouse chronology (Gallagher, 1962). Coll. 1960 and subm. by Patrick Gallagher, George Washington Univ., Washington, D. C. Comment: agrees with other dates for the latter part of Period II.

\section{Rancho Peludo series, Venezuela}

Rancho Peludo is a village on the Río Guasare $\left(11^{\circ} 4^{\prime} \mathrm{N}\right.$ Lat, $72^{\circ} 3^{\prime}$ W Long), ca. $50 \mathrm{~km} \mathrm{NW}$ of Maracaibo, state of Zulia, Venezuela. Refuse is eroding out of the bank of the river between the depths of 1 and $2 \mathrm{~m}$. J. M. Cruxent, of the Inst. Venezolano de Inv. Cient., collected the first sample (Y578) in 1957; remaining samples coll. 1961 by Cruxent and Irving Rouse, to check the validity of the first determination; subm. by Rouse (Rouse and Cruxent, 1963, in press). 


\section{Y-578. Rancho Peludo, Cruxent excavation}

$4630 \pm 150$

2680 в.c.

Charcoal from a depth of 1.80 in the original Cruxent excavation.

Y-1108-I. Rancho Peludo, A1, 1.00 to $1.25 \quad 2330 \pm 80$

Charcoal scattered through Section A-l, Level 1.00 to $1.25 \mathrm{~m}$, of the Cruxent-Rouse excavations.

Y-1108-II. Rancho Peludo, A1, 1.25 to 1.50

$2680 \pm 80$

730 в.с.

Charcoal scattered through Section Al, Level 1.25 to $1.50 \mathrm{~m}$.

Y-1108-III. Rancho Peludo, Al, 1.50 to 1.75

$6190 \pm 90$

Charcoal scattered through Section Al, Level 1.50 to $1.75 \mathrm{~m}$.

Y-1108-IV. Rancho Peludo, A1, 1.75 to $2.00 \quad 13,920 \pm 200$

Charcoal scattered through Section Al, Level 1.75 to $2.00 \mathrm{~m}$.

Y-1109. Rancho Peludo, B1, 1.50 to 1.75

$3750 \pm 80$

1800 в.с.

Charcoal scattered through Section Bl, Level 1.75 to $2.00 \mathrm{~m}$, of the Cruxent-Rouse excavations.

\section{Y-1110. Rancho Peludo, C1, 1.75 to 2.00}

$3810 \pm 90$

1860 в.c.

Charcoal scattered through Section Cl, Level 1.75 to $2.00 \mathrm{~m}$, of the Cruxent-Rouse excavations.

General comment: all these samples are consistent with each other, as well as with their relative depths in the deposit, except Y-1108-III and -IV, which may have been contaminated with charcoal from an underlying Paleo-Indian deposit, brought up through the digging of graves. Otherwise, the samples date a Meso-Indian deposit with pottery of the Rancho Peludo style, referred to Period I and early Period II on the relative time scale.

\section{Paria series, Venezuela}

Charcoal samples from three sites near the end of the Peninsula of Paria, state of Sucre, Venezuela. Coll. 1961 by J. M. Cruxent and Irving Rouse; subm. by Rouse.

\section{Y-1111. Amacuro}

$690 \pm 70$

$$
\text { A.D. } 1260
$$

Charcoal from Section Al, Level $0.25-0.50 \mathrm{~m}$ in the Amacuro site at the tip of the Peninsula of Paria $\left(10^{\circ} 40^{\prime} \mathrm{N}\right.$ Lat, $61^{\circ} 57^{\prime} \mathrm{W}$ Long). Associated with pottery of the Guayabita style, Period IV.

\section{Y-1112. Cabrantica}

$$
\begin{array}{r}
1320 \pm 100 \\
\text { A.D. } 630
\end{array}
$$

Charcoal from Sections A-C, Level 0.50 to $0.75 \mathrm{~m}$ in the Cabrantica site, near Güiria $\left(10^{\circ} 39^{\prime} \mathrm{N}\right.$ Lat, $62^{\circ} 14^{\prime} \mathrm{W}$ Long $)$. Associated with pottery of the Irapa style, Period III. 


\section{Y-1113. Punta de Piedras}

Charcoal from Section G-5, depth of $0.50 \mathrm{~m}$, in the Punta de Piedras site $\left(10^{\circ} 33^{\prime} \mathrm{N}\right.$ Lat, $62^{\circ} 27^{\prime} \mathrm{W}$ Long). Associated with the Irapa style of Period II. General comment: the dates are consistent with the relative chronology for the Peninsula of Paria and with the age of the one sample from there previously analyzed, A.D. 325, which is associated with the Irapa style (Y-290, Yale II; see also Rouse and Cruxent, 1963).

\section{West Indies}

\section{Y-650. Troumassée, St. Lucia}

$1220 \pm 100$

A.D. 730

Charcoal from Pit 6, depth of 60 to 66 in. in field No. 13-11, Troumassée site $\left(13^{\circ} 50^{\prime} \mathrm{N}\right.$ Lat, $60^{\circ} 53^{\prime} \mathrm{W}$ Long), St. Lucia, British West Indies. Coll. 1957 and subm. by Marshall McKusick, State Univ. of Iowa, Iowa City. Comment: Troumassee is the type site for the Period III style of St. Lucia. The date agrees with expectation.

\section{Y-1115. Grand Anse, St. Lucia}

$\mathbf{1 4 6 0} \pm \mathbf{8 0}$

A.D. 490

Charcoal from Grande Anse site ( $14^{\circ} 1^{\prime} \mathrm{N}$ Lat, $60^{\circ} 53^{\prime} \mathrm{W}$ Long), St. Lucia, British West Indies, depth of 66 to 72 in. Coll. Feb. 1961 by W. G. Haag, Louisiana State Univ.; subm. by Irving Rouse. Comment: dates the Troumassée style of Period III and is to be compared with the preceding sample; it is earlier than expected.

\section{Y-1116. La Salle, Martinique}

$1770 \pm 80$

$$
\text { A.D. } 180
$$

Charcoal from La Salle site (14 $46^{\prime} \mathrm{N}$ Lat, $61^{\circ} 0^{\prime} \mathrm{W}$ Long), Sainte Marie, Martinique, French West Indies, depth of 24 to 30 in. Coll. May 1961 by W. G. Haag; subm. by Irving Rouse. Comment: dates the earliest, Saladoid pottery of the island, apparently marking the first movement of Neo-Indians from Venezuela into the Antilles. Agrees fairly well with the date of A.D. 270 for the supposed source of the movement in the Irapa style on the Peninsula of Paria, Venezuela (this list, Y-1113) ; see also next series.

\section{Morel series, Guadeloupe}

Morel $\left(16^{\circ} 19^{\prime} \mathrm{N}\right.$ Lat, $61^{\circ} 19^{\prime} \mathrm{W}$ Long $)$, is a large village site at La Moule on the NE coast of Grande-Terre, Guadeloupe, French West Indies. Coll. 1961 by Edgar Clerc; subm. by Irving Rouse.

\section{Y-1136. Morel, Sector 5}

$$
\begin{array}{r}
1380 \\
\text { A.D. } 570
\end{array}
$$

Charcoal from the base of the refuse, $2.0 \mathrm{~m}$ deep, in Sector 5 .

\section{Y-1137. Morel, Sector 2}

Charcoal from the base of the refuse, $1.5 \mathrm{~m}$ deep, in Sector 2 .

\section{Y-1138. Morel, Sector 3}

$$
1710 \pm 100
$$

A.D. 240

Charcoal from the base of the refuse, $2.0 \mathrm{~m}$ deep, in Sector 3. 
General comment: these samples are associated with the earliest, Saladoid pottery of the island and therefore should date the colonization of the Antilles by Neo-Indians from Venezuela, as does the preceding sample (Y-1116). The agreement between the two is quite good.

\section{White Marl series, Jamaica}

White Marl ( $17^{\circ} 55^{\prime} \mathrm{N}$ Lat, $77^{\circ} 3^{\prime} \mathrm{W}$ Long), is a village site in St. Catherine Parish, Jamaica, British West Indies. Coll. June 1961 and subm. by R. R. Howard, Univ. of Wisconsin, Milwaukee. Comment: White Marl was inhabited by Sub-Taino, who should date from late Period III or Period IV. The following $\mathrm{C}^{14}$ determinations confirm this.

\section{Y-1117. White Marl 3, 50 to 60 in.}

$$
1020 \pm 100
$$
$60 \mathrm{in.}$

Charcoal and coney bone from test trench in midden No. 3, Level 50 to

\section{Y-1118. White Marl 2, 40 to 50 in.}

$1070 \pm 100$ 50 in.

Charcoal and coney bone from test trench in midden No. 2, Level 40 to

Y-1119. White Marl 3, 40 to 50 in.

$620 \pm 100$

Charcoal and coney bone from midden No. 3, Level 40 to 50 in.

\section{Feti la Choya series, Angola}

$$
\text { E. Angola }
$$

Charcoal from a large midden, traditional burial place of Choya, legendary primal queen of the Ovimbundu; part of a large fortified site containing stonework and evidence of intensive iron smelting, $\mathrm{nr}$ confluence of Kuene and Kunyongamua Rivers ( $13^{\circ} 26^{\prime} \mathrm{S}$ Lat, $15^{\circ} 53^{\prime} \mathrm{E}$ Long), Angola. Social anthropology and folklore of the Ovimbundu was described by Childs (1949); site is described in Bol. Inst. Angola, no. 10, p. 55-75, 1957. Samples collected by G. M. Childs, anthropologist and missionary, in a shaft sunk (by treasure hunters) at $\mathrm{S}$ side of midden, where sterile soil was encountered at $2.5 \mathrm{~m}$ depth. Subm. 1958 by M. W. Ennis, 63 N Hancock St., Lexington 73, Mass., for Childs, c.p. 230, Nova Lisboa, Angola.

\section{Y-587. Feti la Choya, bottom}

$$
\begin{array}{r}
1240 \\
\text { A.D. } 710
\end{array}
$$

From bottom layer, overlying sterile soil, accompanied by pottery and animal bones, not yet studied.

\section{Y-588. Feti la Choya, 1 m}

$$
700 \pm 65
$$

\section{A.D. 1250} Y-587.

From lower layer of midden, ca. $1.5 \mathrm{~m}$ above sterile soil, in same shaft as

Comment: Childs notes that while the older date is much older than any previously estimated (for Iron Age material) for Angola, it is not out of line with $\mathrm{C}^{14}$ dates for Iron Age sites in Rhodesia and South Africa. J. Desmond Clark, 
Univ. of California, Berkeley, comments that the dates bracket the time, ca. A.D. 1100, when the first stone walling was being constructed at Zimbabwe, in Rhodesia. Full significance of the Fetila Choya finds in relation to other sites cannot be appraised without study of the pottery, now in the U.S.

\section{GEOCHEMICAL SAMPLES}

The following samples complete the list begun in Yale VI and Yale VII. A paper on carbon isotopes in Linsley Pond is in press (Deevey and Stuiver, in press). Mud-surface samples from Rogers Lake have been used to calculate ages of older sediments (Rogers Lake series, this date list).

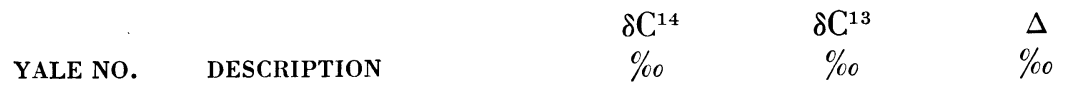

Y-1080. Linsley Potamogeton, outlet, 1961

Potamogeton, nr outlet, Sept, 6,

$$
+68.2 \pm 10-16.6 \quad+50.3 \pm 10
$$
1961.

\section{Y-1081. Linsley Nuphar, September 1961}

$$
+202.6 \pm 10 \quad-23.8 \quad+205.5 \pm 10
$$

Nuphar, Sept. 6, 1961.

\section{Y-1126. Linsley deep December 1961}

Water from $13 \mathrm{~m}$ depth, Dec. 12 ,

$$
-0.2 \pm 7 \quad-12.0 \quad-26.2 \pm 7
$$
1961.

\section{Y-1127. Linsley surface December 1961}

Surface water, Dec. 12, 1961.

$$
+0.7 \pm 7 \quad-6.9 \quad-35.5 \pm 7
$$

Y-1128. Linsley inlet December 1961

Water from N inlet, Dec. 12, 1961.

$$
-37.7 \pm 8 \quad-10.0 \quad-66.6 \pm 8
$$

\section{Y-1148. Linsley deep March 1962}

Water from $13 \mathrm{~m}$ depth, under

$$
-93.9 \pm 8 \quad-8.0 \quad-124.7 \pm 8
$$

ice, Mar. 10, 1962.

Y-1180. Linsley surface mud, 1st

From 0 to $5 \mathrm{~cm}$ below mud-water

$$
-133.0 \pm 10-
$$
interface in core, $14.1 \mathrm{~m}$ depth, coll, June 14, 1962 by E. S. Deevey.

Y-1181. Linsley surface mud, 2nd

From 5 to $10 \mathrm{~cm}$ depth below

$$
-145.0 \pm 10
$$


YALE NO. DESCRIPTION $\delta \mathrm{C}^{14} \quad \delta \mathrm{C}^{13}$

mud-water interface, same core as Y-1180.

Y-1182. Linsley surface mud, 3rd

From 10 to $15 \mathrm{~cm}$ below mud-

water interface, same core as Y-1180.

$$
\begin{aligned}
& -212 \pm 10 \\
& 4 \text { th } \\
& -172 \pm 10
\end{aligned}
$$

From 15 to $20 \mathrm{~cm}$ below mud-

water interface, same core as Y-1180.

\section{Y-1070. Wononscopomuc pondweeds 1961}

Potamogeton, Wononscopomuc

$$
+10.4 \pm 10-16.1 \quad-7.4 \pm 10
$$

Lake, July 31, 1961.

Y-1072. Queechy pondweeds 1961

17, 1961.

Potamogeton, Queechy Lake, July

$-130.8 \pm 10-17.3-144.2 \pm 10$

Y-1101. Queechy well 1961

Hard-water well on Kontak prop-

erty, Queechy Lake, Sept. 24, 1961.

Y-1067. Rogers Nuphar 1961 1961.

Nuphar, Rogers Lake, July 25,

$$
+179.6 \pm 10-23.6+176.3 \pm 10
$$

Y-1068. Rogers pondweeds 1961

Myriophyllum, Rogers Lake, July

$$
+47.2 \pm 10-16.1 \quad-7.4 \pm 10
$$
25, 1961.

Y-1261. Rogers surface mud, lst

From 0 to $9 \mathrm{~cm}$ below mud-water

$$
-103.0 \pm 10
$$

interface, in core, $10 \mathrm{~m}$ depth, $\mathrm{S}$ basin, Rogers Lake, Sept. 10, 1962.

Y-1262. Rogers surface mud, 2nd

From 9 to $23 \mathrm{~cm}$ below mud-water

interface, same core as Y-1261. 
Date lists:

\section{REFERENCES}

$\begin{array}{ll}\text { Isotopes I } & \begin{array}{l}\text { Walton, Trautman, and Friend, 1961 } \\ \text { Crnold and Libby, 1951 } \\ \text { Micago I } \\ \text { Michigan I }\end{array} \text { Crane, 1956 } \\ \text { Michigan IV } & \text { Crane and Griffin, 1959 } \\ \text { Uppsala III } & \text { Olsson et al., 1961 } \\ \text { USGS IV } & \text { Rubin and Alexander, 1958 } \\ \text { USGS V } & \text { Rubin and Alexander, 1960 } \\ \text { Yale II } & \text { Preston, Person, and Deevey, 1955 } \\ \text { Yale III } & \text { Barendsen, Deevey, and Gralenski, 1957 } \\ \text { Yale IV } & \text { Deevey, Gralenski, and Hoffren, 1959 } \\ \text { Yale VI } & \text { Stuiver and Deevey, 1961 } \\ \text { Yale VII } & \text { Stuiver and Deevey, 1962 }\end{array}$

Arnold, J. R., and Libby, W. F., 1951, Radiocarbon dates: Science, v. 113, p. 111-120.

Barendsen, G. W., Deevey, E. S., and Gralenski, L. J., 1957, Yale natural radiocarbon measurements III : Science, v. 126, p. 908-919.

Bloom, A. L., 1960, Late Pleistocene changes of sea level in southwestern Maine: Maine Dept. Econ. Devel., Maine Geol. Surv., Augusta, 143 p.

Bloom, A. L., and Stuiver, Minze, 1963, Submergence of the Connecticut coast: Science, v. 139 , p. $332-334$

Childs, G. M., 1949, Umbundu kinship and character: Oxford Univ. Press, Oxford.

Coe, M. D., 1962, Costa Rican archaeology and Mesoamerica: Southwestern Jour. of Anthropology, v. 18, p. 170-183.

Colinvaux, P. A., in press, A pollen record from Arctic Alaska reaching glacial and Bering Land Bridge times: subm. to Nature, 22 Oct. 1962.

Crane, H. R., 1956, University of Michigan radiocarbon dates I: Science, v. 124, p. 664-672.

Crane, H. R., and Griffin, J. B., 1959, University of Michigan radiocarbon dates IV: Am. Jour. Sci. Radioc. Supp., v. 1, p. 173-198.

Deevey, E. S., 1958, Radiocarbon-dated pollen sequences in eastern North America: Geobot. Inst. Rübel, Zürich, Veröffentl., no. 34, p. 30-37.

- in press, Preliminary account of fossilization of zooplankton in Rogers Lake: Internat. Cong. Limnol., 15th, Madison, 1962, Proc.

Deevey, E. S., and Stuiver, Minze, in press, Distribution of natural isotopes of carbon in Linsley Pond and other New England lakes: subm. to Limnol. \& Oceanog.

Flint, R. F., and Deevey, E. S., 1951, Radiocarbon dating of late-Pleistocene events: Am. Jour. Sci., v. 249, p. 257-300.

Fries, Magnus, 1962, Pollen profiles of late Pleistocene and recent sediments from Weber Lake, Minnesota: Ecology, v. 43, p. 295-308.

Gallagher, Patrick, 1962, La Pitía: El Farol, v. 25, p. 6-14.

Hutchinson, G. E., and Cowgill, U. M., 1963, Chemical examination of a core from Lake Zeribar, Iran: Science, v. 140, p. 67-69.

Jelgersma, Saskia, 1962, A late-glacial pollen diagram from Madelia, south-central Minnesota: Am. Jour. Sci., v. 260, p. 522-529.

Krige, A. V., 1927, An examination of the Tertiary and Quaternary changes of sea-level in South Africa, with special stress on the evidence in favour of a recent world-wide sinking of ocean-level: Univ. Stellenbosch, Ann., v. 5, sec. A, no. 1, p. 1-81.

Langford-Smith, Trevor, 1960, The dead river systems of the Murrumbidgee: Geog. Rev., v. 50, p. $368-389$.

v. 1962 , Riverine plains geochronology: Austral. Jour. Sci., v. 25, p. 96-97.

Leighton, M. M., and Wright, H. E., 1957, Radiocarbon dates of Mankato drift in Minnesota: Science, v. 125, p. 1037-1039.

Leopold, E. B., 1956, Two late-glacial deposits in southern Connecticut: [U.S.] Natl. Acad. Sci., Proc., v. 52, p. 863-867.

Librería de Manuel Porrúa, 1957, Manuscrito pictórico de la cultura Maya sobre piel de mamífero: Librería de Manuel Porrúa, Apdo. Postal 14470, México 1, D.F., México.

Lindeman, R. L., 1941, The developmental history of Cedar Creek Bog, Minn.: Am. Midl. Nat., v. 25 , p. $101-112$.

Maarleveld, G. C., and van der Hammen, T., 1959, The correlation between upper Pleistocene pluvial and glacial stages: Geol. Mijn., n.s., v. 21, p. 40-45.

Martin, A. R. H., in press, Evidence relating to the Quaternary history of the Wilderness Lakes: Geol. Soc. S. Afr., Trans., 1961.

Olsson, Ingrid, Cazeneuve, Horacio, Gustavsson, John, and Karlén, Ingvar, 1961, Uppsala natural radiocarbon measurements III: Radiocarbon, v. 3, p. 81-85. 
Preston, R. S., Person, Elaine, and Deevey, E. S., 1955, Yale natural radiocarbon measurements II: Science, v. 122, p. 954-960.

Redfield, A. C., and Rubin, Meyer, 1962, The age of salt marsh peat and its relation to recent changes in sea level at Barnstable, Massachusetts: [U.S.] Natl. Acad. Sci., Proc., v. 48, p. 1728-1735.

Ritchie, W. A., 1946, A stratified prehistoric site at Brewerton, New York: Research Records of the Rochester Mus. of Arts and Sci., no. 8.

1958, An introduction to Hudson Valley prehistory: New York State Mus. and Sci. Service, Bull. no. 367.

Ritchie, W. A., and Dragoo, D. W., The eastern dispersal of Adena: New York State Mus. and Sci. Service, Bull. no. 379.

Robbins, Maurice, 1959, Wapanucket No. 6, an Archaic village in Middleboro, Massachusetts: Attleboro, Massachusetts Archaeol. Soc.

Rouse, Irving, and Cruxent, J. M., 1963, Venezuelan Archaeology: New Haven, Yale Univ. Press.

Press. in press, Some recent radiocarbon dates for western Venezuela: Amer. Antiquity, v. 28 , no. 4 .

Rubin, Meyer, and Alexander, Corrinne, 1958, U. S. Geological Survey radiocarbon dates IV: Science, v. 127, p. 1476-1487. Supp., v. 2, p. 129-185.
. Seological Survey radiocarbon dates V: Am. Jour. Sci. Radioc.

Selling, O. H., 1948, Studies in Hawaiian pollen statistics. Part III. On the late Quaternary history of the Hawaiian vegetation: Bernice P. Bishop Mus., Honolulu, Spec. Pub. 39,154 p., $27 \mathrm{pl}$.

Stuiver, Minze, and Deevey, E. S., 1961, Yale natural radiocarbon measurements VI: Radiocarbon, v. 3, p. 126-140. 262.

van Zeist, W., and Wright, H. E., 1963, Preliminary pollen studies at Lake Zeribar, Zagros Mountains, southwestern Iran: Science, v. 140, p. 65-67.

Walton, Alan, Trautman, M. A., and Friend, J. P., 1961, Isotopes, Inc., radiocarbon measurements I: Radiocarbon, v. 3, p. 47-59.

Washburn, A. L., and Stuiver, Minze, 1962, Radiocarbon-dated postglacial delevelling in northeast Greenland and its implications: Arctic, v. 15, p. 66-73.

Winter, T. C., 1962, Pollen sequence at Kirchner Marsh, Minnesota: Science, v. 138, p. 526-528.

Wright, H. E., and Rubin, Meyer, 1956, Radiocarbon dates of Mankato drift in Minnesota: Science, v. 124, p. 625-626. 